\title{
Rho GTPases in Intellectual Disability: From Genetics to Therapeutic Opportunities
}

\author{
Valentina Zamboni ${ }^{1}$, Rebecca Jones ${ }^{1}$, Alessandro Umbach ${ }^{1}$, Alessandra Ammoni ${ }^{1}$, \\ Maria Passafaro ${ }^{2}$, Emilio Hirsch 1 (i) and Giorgio R. Merlo ${ }^{1, *}$ \\ 1 Department Molecular Biotechnology and Health Science, University of Torino, Via Nizza 52, \\ 10126 Turin, Italy; valentina.zamboni@unito.it (V.Z.); rebecca.jones@edu.unito.it (R.J.); \\ alessandro.umbach@edu.unito.it (A.U.); alessandra.ammoni@edu.unito.it (A.A.); \\ emilio.hirsch@unito.it (E.H.) \\ 2 National Research Council (CNR) Institute for Neuroscience, Via Luigi Vanvitelli, 32, I-20129 Milan, Italy; \\ m.passafaro@in.cnr.it \\ * Correspondence: giorgioroberto.merlo@unito.it; Tel.: +39-011-670-6449; Fax: +39-011-670-6432
}

Received: 25 May 2018; Accepted: 16 June 2018; Published: 20 June 2018

\begin{abstract}
Rho-class small GTPases are implicated in basic cellular processes at nearly all brain developmental steps, from neurogenesis and migration to axon guidance and synaptic plasticity. GTPases are key signal transducing enzymes that link extracellular cues to the neuronal responses required for the construction of neuronal networks, as well as for synaptic function and plasticity. Rho GTPases are highly regulated by a complex set of activating (GEFs) and inactivating (GAPs) partners, via protein:protein interactions (PPI). Misregulated RhoA, Rac1/Rac3 and cdc42 activity has been linked with intellectual disability (ID) and other neurodevelopmental conditions that comprise ID. All genetic evidences indicate that in these disorders the RhoA pathway is hyperactive while the Rac1 and cdc42 pathways are consistently hypoactive. Adopting cultured neurons for in vitro testing and specific animal models of ID for in vivo examination, the endophenotypes associated with these conditions are emerging and include altered neuronal networking, unbalanced excitation/inhibition and altered synaptic activity and plasticity. As we approach a clearer definition of these phenotype(s) and the role of hyper- and hypo-active GTPases in the construction of neuronal networks, there is an increasing possibility that selective inhibitors and activators might be designed via PPI, or identified by screening, that counteract the misregulation of small GTPases and result in alleviation of the cognitive condition. Here we review all knowledge in support of this possibility.
\end{abstract}

Keywords: RhoA; Rac1; cdc42; intellectual disability; neuronal networks; GTPase pathway

\section{Introduction}

Small GTPases of the Rho class comprise a set of highly conserved signaling GTPases, including RhoA, RhoB and RhoC (the Rho subclass), Rac1, Rac2, Rac3 and RhoG (the Rac subclass) and cdc42, TC10/RhoQ and TCL/RhoJ (the cdc42 subclass). The most extensively studied members of the Rho family in the nervous system are RhoA (ras homologous member A), Rac1 (ras related C3 botulinum toxin substrate 1) and cdc42 (cell division cycle 42) [1].

Similar to other signaling GTPases, they cycle between GTP (active) and GDP (inactive)-bound states. The GTP/GDP cycle is regulated by complex protein:protein interactions (PPI) between the GTPase and various partners that either increase (Guanine nucleotide Exchange Factors, GEFs) or decrease (GTPase-activating proteins, GAP) their function to activate downstream targets.

Although the GTPase has an intrinsic enzymatic ability to cleave GTP to GDP, switching in the inactive state, commonly we refer to hyper- and hypo-active GTPase as its increased or decreased function as a component of a signal transduction pathway. 
Over eighty GEFs and seventy GAPs have been identified, suggesting that Rho GTPase regulation is exquisitely complex. This review will focus on the role of Rho GTPases on neurodevelopement, examine the known GTPase regulators mutated in Intellectual Disability (ID) and discuss emerging opportunities for therapeutic approaches.

\section{The Molecular and Cellular Processes Controlled by Rho GTPases in the Construction of Neural Network}

GTPases of the Rho class are molecular hubs that link extracellular cues with changes in intracellular cytoskeleton dynamics. Changes in cytoskeleton are required to execute cell polarity and cell motility processes such as extending and retracting protrusion, cell migration and change in cell shape $[2,3]$.

Rho GTPases are activated by growth factors, adhesive ligands and guidance cue receptors such as slit, ephrins, netrins, and semaphorins [4,5]. Non-receptor tyrosine kinases, such as Focal Adhesion Kinase (FAK) and Src Family Kinases (SFKs) impact on Rho GTPases and regulate actin dynamic and cell motility [6-9]. Integrin receptors and adhesion molecules ( $N$-cadherin) activate Rho GTPases [10,11]. Activated ion channels, such as $\alpha$-amino-3-hydroxy-5-methyl-4-isoxazolepropionic receptor (AMPAR) and N-methyl-D-aspartate receptor (NMDAR) also impact on Rho GTPases [12].

Cytosolic $\left[\mathrm{Ca}^{2+}\right]$ fluctuations at the growth cone influence Rho GTPase activity and induce changes in the actin cytoskeleton $[13,14]$. For example, Brain-derived neurotrophic factor (BDNF) and netrin activate $\left[\mathrm{Ca}^{2+}\right]$-dependent calmodulin kinase II (CaMKII), which increases Rac1/cdc42 and decreases RhoA activity to promote axon outgrowth [15].

Downstream, GTPases regulate several aspects of cytoskeleton assembly/disassembly, such as actin filament polymerization and severing, actomyosin contractility and microtubule elongation [16]. Specifically, RhoA controls nucleation, elongation, branching and severing of the actin filament network via the Rho kinase-LIM domain kinase (ROCK-LIMK) pathway that impacts on the actin-binding protein actin depolymerizing factor (ADF)/cofilin [17-20]. Rac1 and cdc42 also govern actin cytoskeletal dynamics via ADF/cofilin, however they utilize the p21-activated kinase (PAK)-LIMK pathway [21,22]. Rac1 and cdc42 act on actin dynamic also via WAS protein family member (WAVE) and Wiskott-Aldrich syndrome like (N-WASP), respectively [4]. Actomyosin contractility is regulated by RhoA through the ROCK-myosin light chain (MLC) pathway and by cdc42 via the PAK-MLC kinase (MLCK) pathway [23].

Actin polymerization, increased myosin II motor function and active association of actin-binding proteins with adhesion complexes promote neurite elongation and leading edge progression. The phosphorylation of shootin1 downstream of Rac has been recognized as a key mechanism to couple enhanced actin flow with cell adhesion via a linking bridge, known as a "clutch" [22,24,25].

GTPases also control microtubule elongation [26]: Rac1 and cdc42 use PAK kinases as downstream targets, which can act through Op18 and control microtubule growth. Moreover Rac1 and cdc42 regulate neuronal migration and the formation of leading process of migrating neurons via the activation of the downstream c-Jun N-terminal kinase (JNK)-microtubule pathway through the association with IQ motif containing GTPase activating protein 1 (IQGAP1) [27,28]. Instead RhoA acts on the regulation of microtubule stabilization through Dia [29,30].

The Rho, Rac1 and cdc42 trasduction pathways converge and diverge at different levels of the pathways. All these convergent and divergent pathways are tightly controlled by a complex and multi-layered set of regulators (GAPs, GEFs and other less well understood). For example RhoA, Rac1 and cdc42 promote actin polymerization via LIMK activation, while actomyosin contractility promoted by RhoA is inhibited by Rac1 and cdc42 through inhibition of MLCK [23].

The actions of Rho GTPases depend on the developmental time. At early stages the control of cytoskeletal dynamics is essential for the acquisition of cell polarity, hence for neurogenesis; indeed loss of RhoA results in three distinct cortical malformations: (1) a defect in the proliferation of progenitor cells leading to a bigger cerebral cortex; (2) a change in the morphology of radial glial cells with 
the formation of a subcortical band eterotopia; (3) an increase in the speed of migrating newborn neurons [31]. At later developmental stages, the control of cytoskeletal dynamics is essential for axonogenesis, dendritogenesis, axon guidance and neuronal migration [3,4], hence required for the construction of the excitatory and inhibitory networks and their complexity. For this reason, changes of the spatiotemporal activity of small GTPases, such as those due to mutations in GAPs and GEFs, affect neuronal migration, dendrite extension and complexity, axon extension and guidance, and spine shape and plasticity, resulting in ID and other cognitive deficits.

Rac and cdc42 are generally associated with promotion of elongation, branching, and complexity, while RhoA is generally associated with the opposite: Inhibition of elongation, branching, and complexity [32]. However this notion is based on in vitro studies that use overexpression of dominant-negative $(\mathrm{DN})$ and constitutively-active (CA) mutants, while in vivo studies have not always confirmed this notion.

In adult neurons, small GTPases control dynamic events of the actin cytoskeleton of the dendritic spine (the postsynaptic compartment) of the excitatory synapse [33-35], thus participating in the synaptic plasticity and the maturation of cognitive functions.

Finally, a novel function of small GTPases in the control of ROS production has recently been shown [36,37]. Whether this could represent a unifying mechanisms that participates in the endophenotype leading to ID remains to be further investigated.

\subsection{GAP and GEF at the Growth Cone}

RhoA, Rac1 and cdc42 connect a wide spectrum of external guidance molecules to cytoskeletal changes and thereby regulate the growth cone morphology and dynamic of the growth cone and assure the directed elongation of neuronal processes. A tight regulation through GAPs (such as $\alpha$-chimaerin, ArhGAP15 and SrGAPs) and GEFs (such as ALS2, Sos, BPix, Kalirin, Trio, Ephexin1, Lfc and Intersectin) is determinant for controlling growth cone protrusion, growth cone collapse and neurite retraction (Figure 1).

$\alpha$-chimaerin is a GAP for Rac1 that mediates EphrinB3/EphA4 signaling during the formation of motor neuron circuits, via inactivation of Rac1. In cultured hippocampal neurons, EphrinA-induced growth cone collapse is associated with tyrosine phosphorylation of $\alpha 2$-chimaerin and inhibition of the Rac-PAK pathway [38,39].

Trio is essential for netrin1-induced axon elongation and guidance. Trio displays two GEF domains of distinct specificity: Ras guanine nucleotide exchange factor1 (GEFD1) activates the small GTPases RhoG and Rac1, whereas GEFD2 acts on RhoA. Trio-induced neurite outgrowth is mediated by the GEFD1-dependent activation of RhoG, previously shown to be part of the nerve growth factor (NGF) pathway [40]. The chaperone activity of Hsc70 is required for Rac1 activation by Trio and this function underlies netrin-1/DCC-dependent axon outgrowth and guidance [41]. In response to netrin-1 Trio is phosphorylated (Y2622) by Src family kinases, and this step is essential for the regulation of the DCC/Trio signaling complex during axon outgrowth [42].

The chemorepulsive molecule Slit signals via the Robo1/2 receptors. SrGAPs are recruited downstream of this signaling, locally inactivates Rho GTPases thereby reducing actin polymerization asymmetrically, and leading to subsequent turning of the growth cone away from Slit [43]. In response to the Slit/Robo activation, Sos is also recruited to the plasma membrane where it forms a ternary complex with Robo1/2 and the SH3-SH2 adaptor protein DOCK to regulate Rac-dependent cytoskeleton rearrangement [44].

Lfc localizes at the growth cones of developing neurons and negatively regulates neurite sprouting and axon formation via its GEF activity on the Rho signaling pathway. Tctex-1, a dynein light chain implicated in axon outgrowth by modulating actin dynamics and Rac activity, colocalizes and physically interacts with Lfc, thereby inhibiting its GEF activity, decreasing Rho-GTP levels and functionally antagonizing Lfc during neuritogenesis [45].

ArhGAP15 is a Rac1-specific brain-specific GAP and its loss leads to an overall reduced efficiency of neurite elongation and branching, and a simpler morphology of pyramidal and hippocampal 
neurons [21,25]. Finally, ALS2/Alsin is a Rac1 GEF, that colocalizes with Rac1 within growth cones and promotes neurite outgrowth [46]. Interestingly, ALS2 has been proposed also as a Rac1 effector, thus acting as a bifunctional protein [47].

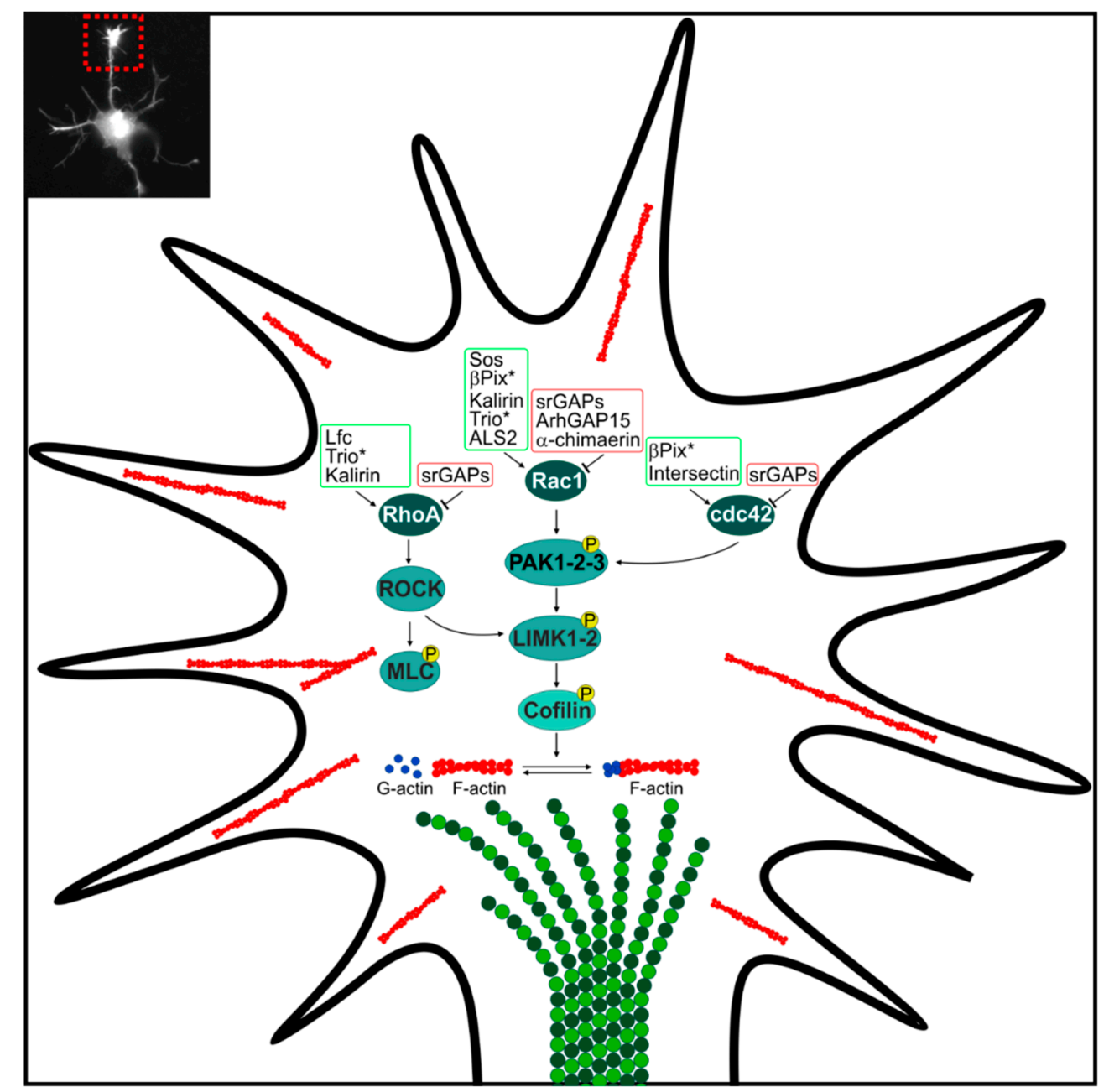

Figure 1. Regulations of Rho GTPases at the growth cone, by GTPase-activating proteins (GAPs) and Guanine nucleotide Exchange Factors (GEFs) implicated in Intellectual Disability. Green and red boxes surround GEF and GAP proteins, respectively. Asterisks indicate that are mutated in Intellectual Disability (ID) and other human diseases comprising ID. Circled P indicates phosphorylation. Arrows indicate activation, $\mathrm{T}$ bars indicate inhibition. A representative small magnification image of a growth cone is provided in the inset (top left). ROCK, Rho kinase-LIM domain kinase; MLC, myosin light chain; PAK1-2-3, p21-activated kinase 1-2-3; LIMK1-2, Rho kinase-LIM domain kinase 1-2.

\subsection{GAP and GEF at the Leading Edge}

The molecules that regulate Rho GTPases in this location are illustrated in Figure 2. Rho GTPases present at the leading edge participate in the process of neuronal migration, both radial and tangential. Both types of migration of immature GABAergic neurons are impaired in mice with a combined loss of Rac1 and Rac3 [48]. Loss of ArhGAP15 leads to hyperactive Rac1 pathway and affects the tangential migration of hippocampal interneurons [21,48]. Loss of $\alpha$-chimaerin results in aberrant radial migration and accumulation of ectopic neurons in subcortical regions [49]. SrGAP2 is required for the efficient production of branches of the leading process [50]. Notably, all these GAP molecules are active on Rac1. 


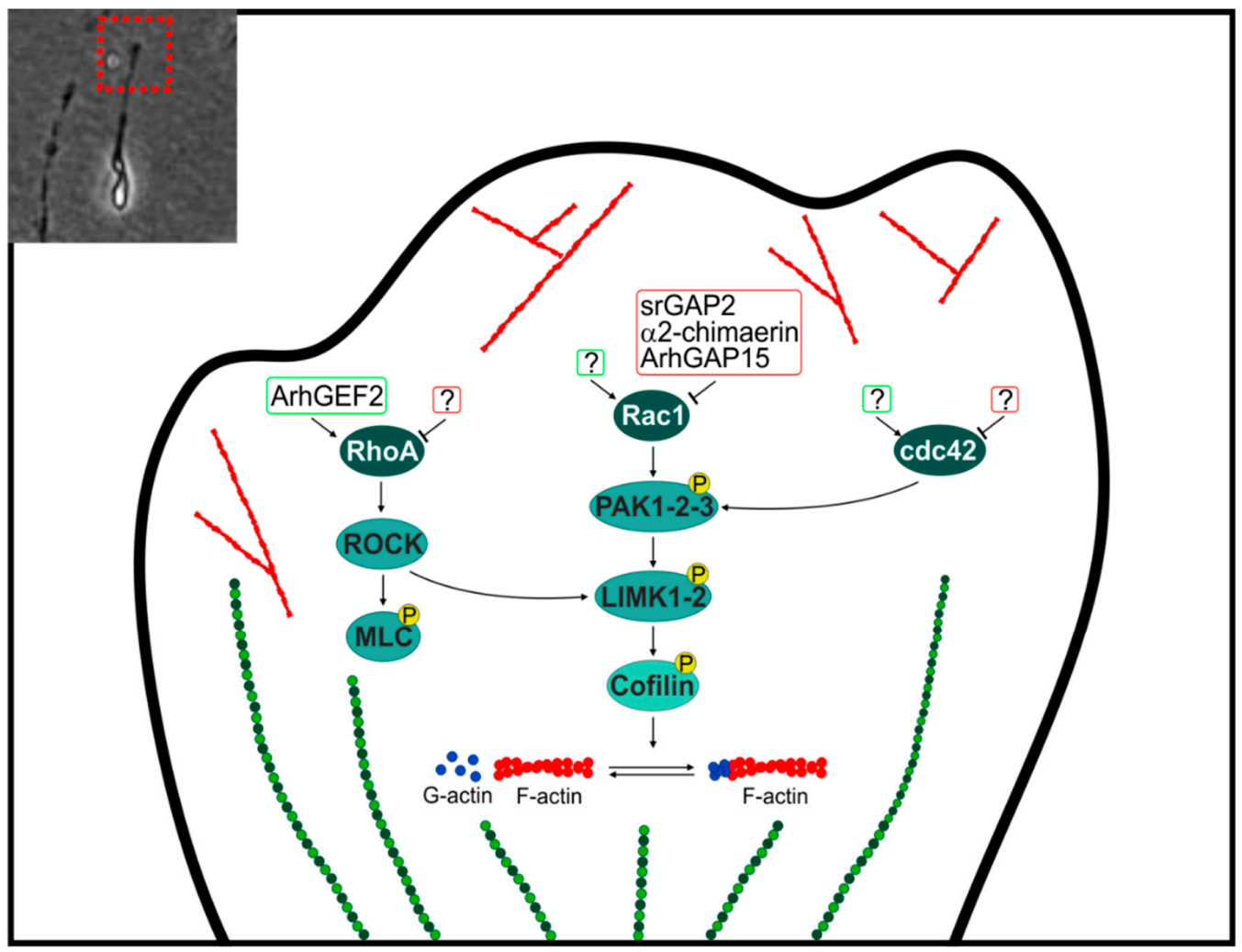

Figure 2. Regulations of Rho GTPases at the leading edge of a migrating neuron, by GAPs and GEFs implicated in Intellectual Disability. Green and red boxes surround GEF and GAP proteins, respectively. Circled $\mathrm{P}$ indicates phosphorylation. Arrows indicate activation, $\mathrm{T}$ bars indicate inhibition. A representative small magnification image of a migrating neuron with an evident leading edge is provided in the inset (top left). ROCK, Rho kinase-LIM domain kinase; MLC, myosin light chain; PAK1-2-3, p21-activated kinase 1-2-3; LIMK1-2, Rho kinase-LIM domain kinase 1-2.

Homozygous frameshift mutations in the ARHGEF2 gene have been identified as cause of ID. The loss of normal ARHGEF2 activity leads to reduced activation of the RhoA-ROCK-MLC pathway, which in turn is crucial for cell migration. Indeed, $A r h G E F 2^{-/-}$mice exhibit altered migration of precerebellar immature neurons [51].

AUTS2 (Autism susceptibility candidate 2 gene) acts as an upstream factor of Rac1 and cdc42, regulating the cytoskeletal rearrangements in neural cells. Indeed AUTS2 induces lamellipodia in neuroblastoma cells and promotes neurite extensions of cultured hippocampal neurons, via activation of Rac1 [52]. The AUTS2-Rac1 pathway is required for neuronal migration and subsequent neuritogenesis in the cerebral cortex [53]. Conversely, AUTS2 acts as a suppressor of cdc42 and inhibits filopodia formation [53].

The two ROCK isoforms ROCK1 and ROCK2 differentially regulate distinct pathways downstream of RhoA, and their coordinated activities drive cell polarity during migration and synaptogenesis. ROCK1 forms stable actomyosin filament bundles that initiate front-back and dendritic spine polarity. In contrast, ROCK2 regulates contractile forces and Rac1 activity at the leading edge and at the spine head; it also specifically regulates $\mathrm{ADF} /$ cofilin-mediated actin remodeling that underlies the maturation of adhesions and the postsynaptic density (PSD) of dendritic spines [54].

RhoG plays a key role in regulating actin dynamics at the leading edge during neural migration, by acting downstream of anillin [55], but its regulation through GAPs and GEFs has been poorly explored. 


\subsection{GAP and GEF at the Dendritic Spine}

Rho GTPases have been shown to control dendritic spine morphology and plasticity [56]. In general, RhoA activation has a negative effect on spine growth and maturation, whereas Rac1 and cdc42 promote spine formation and maintenance [57]. The specific molecules that regulate Rho GTPases in this location are illustrated in Figure 3. Recent proteomic efforts focused on the PSD place GTPases and their regulatory machinery in a highly connected domain-domain interaction context, linked to several other molecules implicated in neurodevelopmental disorders, including ID [58].

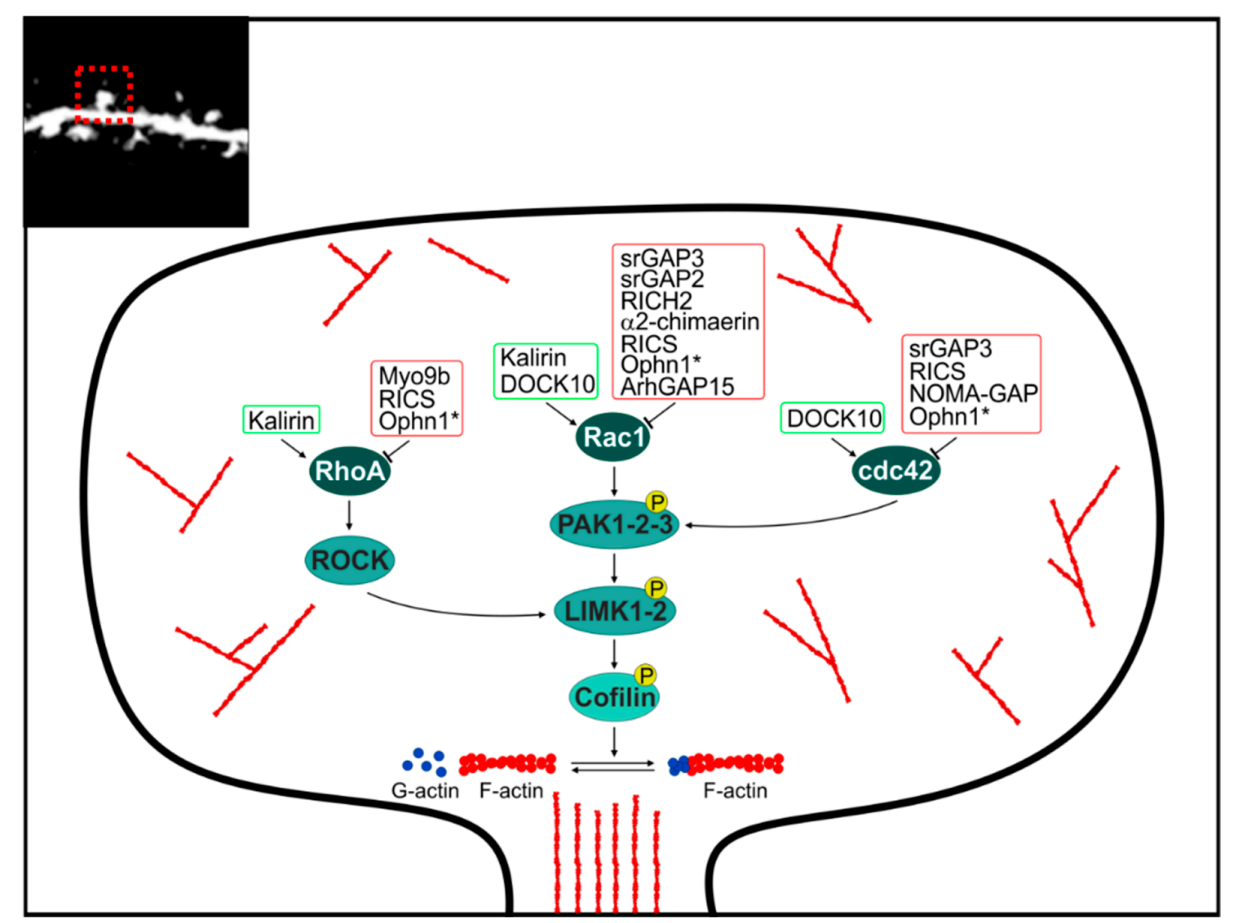

Figure 3. Regulations of Rho GTPases at the dendritic spine of an excitatory synapse, by GAPs and GEFs implicated in Intellectual Disability. Green and red boxes surround GEF and GAP proteins, respectively. Asterisks indicate genes that are mutated in ID and other human diseases comprising ID. Circled P indicates phosphorylation. Arrows indicate activation, $\mathrm{T}$ bars indicate inhibition. A representative small magnification image of a dendritic spine is provided in the inset (top left). ROCK, Rho kinase-LIM domain kinase; RICS, Rho GTPase activating protein 32; DOCK10, dedicator of cytokinesis 10; RICH2, Rho GTPase activating protein 44; PAK1-2-3, p21-activated kinase 1-2-3; LIMK1-2, Rho kinase-LIM domain kinase 1-2.

SrGAPs (including SrGAP2 and SrGAP3) are required for the formation of dendritic spines of excitatory synapses, in vivo. Neurons in which SrGAP2 was silenced displayed immature-shaped spines with smaller heads and longer necks, while upon srGAP2 over-expression most spines display an enlarged and mushroom morphology, thus suggesting that srGAP2 is required to promote spine maturation [50]. SrGAP3 null mice have significantly fewer spines than controls, and even heterozygous mice have fewer mature mushroom-shaped spines [43]. Wave1 mutant mice, in which the Wave1 mutation results in loss of binding between Wave1 and SrGAP3, display spine defects [59].

RICH2 is a Rho-GAP which regulates synaptic spine plasticity. RICH2 was identified as an interaction partner of the scaffolding protein SHANK3 at the PSD. In the amygdala of RICH2 null mice RhoA pathway is hyperactive, actin polymerization is reduced and the density of mature spines is decreased [60]. Their hippocampus and cerebellum display increased multiple spine synapses along with altered receptor composition and actin polymerization [60]. RICH2 null mice display a significant fear for novel objects and increased stereotypic behavior as well as impairment of motor learning. 
Loss of $\alpha 2$-chimaerin induces the formation of aberrant polymorphic dendritic spines, acting via Rac1 hyperactivity. Upon loss of $\alpha 2$-chimaerin the complexity of dendritic arbor is reduced and the number of spines that appear poly-innervated is increased [61].

The knockdown of Myo9b or of Rho GTPase activating protein 32 (RICS) results in defects of dendritic morphology, reverted by the inhibition of RhoA/ROCK pathway. These observations provide further supporting evidence for a key physiological function of RhoA in the regulation of dendritic development [62].

Rho GTPase activating protein 33 (NOMA-GAP) acts through the inactivation of cdc42 and its depletion leads to a marked reduction in the number of dendrite branches of layer $2 / 3$ neurons and mislocalization of glutamatergic receptors [63-65]. Endocytic recycling of AMPARs at the excitatory synapse is important for the supply of a mobile pool of AMPARs required for synaptic potentiation. This local recycling of AMPARs critically relies on the presence of an endocytic zone (EZ) near the PSD. The precise mechanisms that couple the EZ to the PSD remain still largely elusive, with the large GTPase Dynamin-3 and the multimeric adaptor protein Homer1 as the suspected main players. The PPI between Ophn 1 and Homer1b/c is crucial for the positioning of the EZ adjacent to the PSD. Disruption of this interaction causes a displacement of EZs from the PSD, impaired AMPAR recycling and reduced AMPAR accumulation at synapses [66].

Loss of the Rac GEF Kalirin results in reduced spine density and reduced dendrite complexity in layer $\mathrm{V}$ pyramidal neurons of the frontal cortex $[67,68]$.

Finally, DOCK10 GEF and Ephexin5 are implicated in dendritic spine formation and, the first one acting via Rac1 and cdc42, the second via RhoA [69,70].

The existence of a large number of GAPs and GEFs suggests that some of them are specific to a subcellular compartment and/or they are expressed in different times during development. Only two molecules are shared in all three compartments (the growth cone, the leading edge and the dendritic spine); these are SrGAPs and $\alpha$-chimaerins $[38,39,43,49,61]$. This suggests that, while GTPases represent the molecular hubs, the regulation and specificity — hence the adequate cell response-is provided by the regulators. Clearly a better comprehension of the spatiotemporal regulation of Rho GTPases is needed and this could derive from proteomic and interactomic data. Moreover, we note that most studies on Rho GTPases have been done in excitatory synapses, although inhibitory synapses are also plastic. Since excitation/inhibition imbalance is frequently observed in animal models of ID and Autism Spectrum Disorder (ASD), these synapses are evidently important for neurologic and cognitive activities in both the cortex and hippocampus [71,72]. Future studies are needed in this direction.

\section{Rho GTPases and Intellectual Disability}

Intellectual Disability (ID) is a common neurodevelopmental disorder in children, characterized by significant limitations in both intellectual functioning and in adaptive behaviors as expressed in conceptual, social and practical adaptive skills. Estimates of the prevalence of ID among children in the United States based on epidemiologic studies range from 9 to 36 in 1000, depending on the inclusion criteria [73-75]. ID is manifested as both syndromic and nonsyndromic forms, depending on whether the disability is associated with other symptoms. A large fraction of ID is linked to the X-chromosome, and are known as X-linked ID, leading to a higher prevalence of ID in males versus females.

Hundreds of mutations have been detected in ID, both syndromic and nonsyndromic. X-linked ID has been associated with mutations in more than eighty genes on the X-chromosome, some of which code for regulators of the small-GTPase family including: oligophrenin 1 (OPHN1), PAK3, Rac/Cdc42 guanine nucleotide exchange factor 6 ( $\alpha$ PIX), ARHGEF9, FYVE, RhoGEF and PH domain containing 1 (FGD1) and trio Rho guanine nucleotide exchange factor (TRIO) [71,76-78].

Limited evidence is available that the cerebral cortex and the hippocampus of ID children have structural differences. Neuroimaging data suggest differences with limited diagnostic and research value [79-81]. Conversely, genetically modified mice are currently the key in vivo approach to investigate the role of gene mutations in ID and related phenotypes, for determining the basic 
mechanisms, the neurobiological substrates and the neural basis of cognitive function as well as for testing the efficacy of potential therapeutic drugs [82]. Based on a wide spectrum of experimental data from animal models and cultured neurons, it is widely accepted that the cognitive deficits of ID are linked to defects in neuronal networking, synaptic plasticity and the excitation/inhibition balance of the cerebral cortex and hippocampus, and these alterations result in abnormal information processing [83-88]. However, a unifying mechanisms is still elusive. In this direction, recent proteomic and interactomic data, obtained from sinaptosomes, intersected with the gene mutations linked to neurodevelopmental disorders including ID, substantially confirm that "GTPase control" is a highly connected molecular hub [58].

Here we review in details the functions of the main genes mutated in human ID, analyzing the consequence of these mutations in culture systems and in the mouse models currently available, in terms of neuronal morphology, dendrite and axon complexity, spine shape and density, synaptic physiology and plasticity. Table 1 summarizes the main cellular phenotypes of mouse models of ID, related to altered GTPase functions, focusing on dendrites, axon, spine and synaptic properties.

\subsection{Mutations of OPHN1}

The Oligophrenin-1 (OPHN-1) gene, located on chromosome Xq12, codes for a GAP that negatively modulates RhoA activity by promoting GTP hydrolysis [89]. A number of loss-of-function mutations of the OPHN1 gene have been detected in patients with mild X-linked ID [90-93].

Ophn1 is ubiquitously expressed in the developing and adult central nervous system (CNS) $[89,90,94,95]$. The protein is detected both in glial cells and neurons where it colocalizes with F-actin, notably at the tip of growing dendrites [89] and at both sides of the synapse [66,96-98].

In vitro and in vivo studies demonstrated that the loss of OPHN1 results in increased activity of the RhoA GTPase, and to a lesser extent Rac1 and cdc42, and this affects dendritic tree complexity and synaptic functions of hippocampal neurons [90,98-101]. Indeed the inactivation of OPHN1 function induces reduced evoked and spontaneous excitatory postsynaptic currents (EPSCs) and inhibitory postsynaptic currents (IPSCs), associated with decreased readily releasable pool and vesicle recycling, indicating altered neurotransmitter release from the presynaptic processes $[94,101]$.

This altered short-term plasticity is associated with a reduction in mature mushroom-shaped dendritic spines [94,99]. It would be interesting to investigate whether the dysfunction in the neurotransmitter release is the cause or the consequence of the immaturity of dendritic spines in Ophn1 knock-out (KO) mice.

The loss of $O p h n 1$ in mice also recapitulates some behavioral, social, and cognitive impairments of the human phenotypes. Indeed Ophn1 KO mice exhibit behavioral defects in spatial memory together with impairment in social behavior, lateralization, and novelty driven hyperactivity [94].

\subsection{Mutations of RAC1}

RAC1 is a highly conserved gene, located on chromosome 7p22.1, coding for the small GTPase RAC1 and the neural-specific, developmentally regulated isoform RAC1B [102-104]. Rac1 is strongly enriched at the PSD [105]. 
Table 1. The main cellular phenotypes of ID mouse models, related to altered GTPase functions, focusing on dendrites, axon, spine and synaptic properties.

\begin{tabular}{|c|c|c|c|c|}
\hline Gene Mutated in ID & Genetic Mouse Models & GTPase Pathway Activity ${ }^{(1)}$ & Major Phenotypes ${ }^{(2)}$ & References \\
\hline \multicolumn{5}{|c|}{ Dendrite and Axon Development } \\
\hline Oligophrenin1 & Ophn1-ly & $\uparrow$ RhoA & $\downarrow$ dendritic tree complexity of dentate gyrus granule neurons & Powell et al., 2012 [101] \\
\hline$\alpha$-PIX (ArhGEF6) & $\alpha$-Pix KO & $\downarrow$ Rac1 and cdc42 & $\uparrow$ dendrite length in CA1 hippocampus & Ramakers et al., 2012 [106] \\
\hline TRIO & Trio ${ }^{\text {floxfflox}} ;$ Nestin-Cre & $\downarrow$ Rac1, RhoG and RhoA & $\begin{array}{l}\text { Short and highly branched processes of cerebellar granule cells } \\
\downarrow \text { axon length and irregular growth cone of cerebellar granule cells }\end{array}$ & Peng et al., 2010 [107] \\
\hline Rac1 & Rac1 ${ }^{f l o x}$ flox $;$ Foxg1-CRE & $\downarrow$ Rac1 & $\begin{array}{l}\uparrow \text { number of primary neurites and secondary branches in } \\
\text { hippocampal neurons } \\
\text { Absence of the anterior commissure } \\
\text { Corpus callosal axons fail to cross the midline } \\
\text { Defasciculation of thalamocortical and corticothalamic axons and } \\
\text { projection defects }\end{array}$ & Chen et al., 2007 [108] \\
\hline LIMK & LIMK-1 KO & $\downarrow$ Rac1, cdc42 and RhoA & $\downarrow$ size of the growth cone of hippocampal neurons & Meng et al., 2002 [109] \\
\hline \multicolumn{5}{|c|}{ Spine Density and Spine Morphology } \\
\hline Oligophrenin 1 & Ophn1-ly & $\uparrow$ RhoA & $\begin{array}{l}\downarrow \text { density of mushroom-shaped spines on apical dendrites of } \\
\text { CA1 pyramidal neurons of the hippocampus } \\
\downarrow \text { length of spines on basal dendrites of CA1 pyramidal neurons of } \\
\text { the hippocampus } \\
\downarrow \text { density of mushroom-shaped spines of dentate gyrus } \\
\text { granule neurons }\end{array}$ & $\begin{array}{l}\text { Khelfaoui et al., } 2007 \text { [94] } \\
\text { Powell et al., } 2012 \text { [101] }\end{array}$ \\
\hline$\alpha$-PIX (ArhGEF6) & $\alpha$-Pix KO & $\downarrow$ Rac1 and cdc42 & $\uparrow$ spine density in the hippocampus & Ramakers et al., 2012 [106] \\
\hline Rac1 & $\begin{array}{l}\text { Rac1 } 1^{\text {flox/flox; }} \text {; CamKII-CRE } \\
\text { Rac1 } 1^{\text {floxfflox; }} \text { Syn1-Cre }\end{array}$ & $\downarrow$ Rac1 & $\begin{array}{l}\downarrow \text { spine density in the hippocampus } \\
\downarrow \text { PV-positive GABAergic presynaptic terminals in } \\
\text { hippocampal pyramidal layer }\end{array}$ & $\begin{array}{l}\text { Bongmba et al., } 2011 \text { [110] } \\
\text { Pennucci et al., } 2016 \text { [111] }\end{array}$ \\
\hline PAK3 & dnPAK & $\downarrow$ Rac1 and cdc42 & $\downarrow$ spine density of pyramidal cortical neurons & Hayashi et al., 2004 [112] \\
\hline LIMK & LIMK-1 KO & $\downarrow$ Rac1, cdc42 and RhoA & Altered spine shape & Meng et al., 2002 [109] \\
\hline \multicolumn{5}{|c|}{ Synaptic Transmission and Plasticity } \\
\hline Oligophrenin1 & Ophn1-ly & $\uparrow$ RhoA & $\begin{array}{l}\text { Altered neurotransmitter release in the hippocampus } \\
\downarrow \text { evoked EPSC amplitude and spontaneous EPSC frequency of } \\
\text { dentate gyrus granule neurons } \\
\downarrow \text { evoked IPSC amplitude and spontaneous IPSCs frequency in } \\
\text { hippocampal slices } \\
\text { Impaired vesicle recycling dynamics }\end{array}$ & $\begin{array}{l}\text { Khelfaoui et al., } 2007 \text { [94] } \\
\text { Powell et al., } 2012 \text { [101] }\end{array}$ \\
\hline$\alpha$-PIX (ArhGEF6) & $\alpha-P i x \mathrm{KO}$ & $\downarrow$ Rac1 and cdc42 & $\begin{array}{l}\downarrow \text { synapse density } \\
\downarrow \text { early-phase LTP and } \uparrow \text { LTD in CA1 hippocampus }\end{array}$ & Ramakers et al., 2012 [106] \\
\hline
\end{tabular}


Table 1. Cont.

\begin{tabular}{|c|c|c|c|c|}
\hline Gene Mutated in ID & Genetic Mouse Models & GTPase Pathway Activity ${ }^{(1)}$ & Major Phenotypes ${ }^{(2)}$ & References \\
\hline TRIO & Trio KD neurons & $\downarrow$ Rac1, RhoG and RhoA & $\begin{array}{l}\downarrow \text { EPSC frequency } \\
\uparrow \text { AMPAR-mediated synaptic transmission } \\
\downarrow \text { AMPAR endocytosis rate }\end{array}$ & Ba et al., 2016 [113] \\
\hline ArhGEF9 & ArhGEF9 KO & $\downarrow$ cdc42 & $\begin{array}{l}\downarrow \text { postsynaptic gephyrin and } \mathrm{GABA}_{\mathrm{A}} \text { receptor clusters in } \\
\text { the hippocampus } \\
\downarrow \text { mIPSC frequency and amplitude of CA1 pyramidal neurons of } \\
\text { the hippocampus } \\
\uparrow \text { LTP and } \downarrow \text { LTD in the hippocampus }\end{array}$ & $\begin{array}{l}\text { Jedlicka et al., } 2009 \text { [114] } \\
\text { Papadopoulos et al., 2007 [115] }\end{array}$ \\
\hline Rac1 & Rac1 flox/flox; Syn1-Cre & $\downarrow$ Rac1 & $\begin{array}{l}\downarrow \text { frequency and amplitude of the sIPSCs of hippocampal } \\
\text { pyramidal neurons } \\
\text { Impaired synchronization of cortical networks and abnormal } \\
\text { brain activity }\end{array}$ & Pennucci et al., 2016 [111] \\
\hline PAK3 & $d n P A K$ & $\downarrow$ Rac1 and cdc42 & $\begin{array}{l}\text { Altered presynaptic structure in the cortex } \\
\uparrow \text { AMPAR- and NMDAR-mediated synaptic transmission in the } \\
\text { cortex } \\
\uparrow \text { LTP and } \downarrow \text { LTD in the cortex }\end{array}$ & Hayashi et al., 2004 [112] \\
\hline LIMK & LIMK-1 KO & $\downarrow$ Rac1, cdc42 and RhoA & $\begin{array}{l}\uparrow \text { LTP in the hippocampus } \\
\text { Faster synaptic depression and } \uparrow \text { frequency of mEPSCs in the } \\
\text { hippocampus }\end{array}$ & Meng et al., 2002 [109] \\
\hline
\end{tabular}

(1) RhoA/Rac1/cdc42 GTPase pathway activity as a consequence of the mutation of gene related to ID. $\uparrow$ and $\downarrow$ indicate an increased and a decreased signaling pathway, respectively. (2) Abbreviations: AMPAR, $\alpha$-amino-3-hydroxy-5-methyl-4-isoxazolepropionic acid receptor; EPSC, excitatory postsynaptic currents; IPSC, inhibitory postsynaptic currents; LTD, long-term

depression; LTP, long-term potentiation; mEPSC, miniature excitatory postsynaptic currents; mIPSC, miniature inhibitory postsynaptic currents; NMDAR, N-methyl-D-aspartate receptor;

PV, parvalbumin. 
By exome sequencing of 2104 ID parent/children trios, two non-synonymous $R A C 1$ mutations were identified which generate dominant-negative $(\mathrm{DN})$ alleles and are expected to result in a condition of haploinsufficiency and hypoactivity of RAC1 [77,78]. Children carrying these mutations also show microcephaly, thus these mutations affect neuronal proliferation. A subsequent study based on whole-exome sequencing (WES) has demonstrated that, depending on where the mutation of RAC1 occurs, the additional phenotypes observed were: Microcephaly for c53.G > A (pCys18Tyr), c116A > G (pAsn39Ser), c218C > T (p.Pro73Leu) and c470G > A (p.Cys157Tyr) variants, macrocephaly for c151G > A (p.Val51Met) and c151G > C (p.Val51Leu) alleles and normal size for c.190T > G (p.Tyr64Asp) allele [78].

In vitro, the functions of the Rac1 have been studied mostly by expressing DN or constitutively active (CA) mutants, and indicate a critical role of Rac1 in neuritogenesis and neuronal migration [23]. The expression of DN Rac1 in cultured cortical neurons markedly reduces the number of primary and basal dendrites in neurons with pyramidal morphologies, indicating that Rac is required for the elaboration of dendritic processes [116]. Conversely, the expression of CA Rac leads to the elaboration of dendritic processes [116]. Moreover the expression of DN Rac1 results in a progressive elimination of dendritic spines, whereas hyperactivation of RhoA causes a drastic simplification of dendritic branch patterns that is dependent on the activity of the RhoA target ROCK [117]. Overall, the results obtained with these in vitro approaches are compromised by the artificial conditions of overexpressed mutant protein and the abundant crosstalk between members of the Rho GTPases family.

In vivo, the full $\mathrm{KO}$ of Rac1 in mice leads to embryonic lethality [118], therefore models of conditional deletion of Rac1 in the CNS have been generated, including:

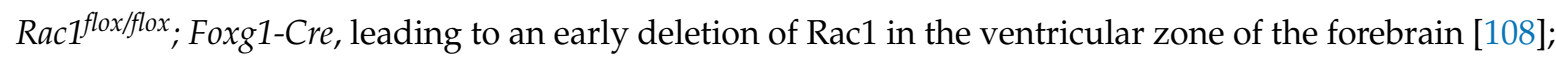
Rac1 flox/flox; Syn1-Cre, named Rac1N, leading to a later deletion of Rac1 in differentiating neurons [111]; Rac floxflox; CamKII-Cre, leading to a brain specific deletion of Rac1 in the hippocampus [110];

Rac1 flox/flox; Nkx2.1Tg-Cre, leading an early deletion of Rac1 in the medial ganglionic eminence (MGE) [119].

The deletion of Rac1 in ventricular zone (VZ) progenitors does not prevent the axonal outgrowth of telencephalic neurons [108]. However, the anterior commissure is absent, and the corpus callosum as well as hippocampal commissural axons fail to cross the midline in Rac1 $1^{\text {flox/flox; }}$ Foxg1-Cre KO embryos. The thalamocortical and corticothalamic axons also show defasciculation or projection defects [108]. In contrast to previous studies using DN mutants, these results suggest that Rac1 controls axon guidance rather than neuritogenesis. The specific deletion of Rac1 in the hippocampus induces a reduced spine density [110].

In the hippocampal pyramidal layer of Rac1N mice, Pennucci and colleagues have observed a significant decrease of PV-positive GABAergic presynaptic terminals [111]. They observe no differences in membrane capacitance, input resistance, and membrane resting potential, all of which are passive properties of pyramidal neurons [111]. Instead, hippocampal pyramidal neurons show reduced frequency and amplitude of the sIPSCs [111].

Rac1N mice show generalized hyperactivity and impaired hippocampal-dependent spatial, working and learning and memories [111]. Moreover, quantitative electroencephalography (EEG) analysis revealed impaired synchronization of cortical networks and abnormal brain activity, with slower $\theta-\alpha$ rhythms significantly evident in these mice [111].

\subsection{Rac1 and GABAergic Neurons}

Inhibitory GABAergic interneurons play fundamental roles in modulating cortical and hippocampal neuronal circuits $[120,121]$. The altered neurogenesis and/or migration of these neurons may alter the balance between excitatory and inhibitory activities that is required for proper brain function, a dysfunction thought to be at the basis of various neurological and cognitive conditions including ID, ASD, epilepsy and schizophrenia [122]. 
Several extracellular cues drive the migration and differentiation of the cortical and hippocampal GABAergic cells, while little is known about the intracellular mechanisms that underlie their motility responses [123]. Some recent studies have established that Rac proteins are essentially required for the development of cortical and hippocampal GABAergic interneurons. Rac1 is required for the exit from the cell cycle of the MGE-born interneuron precursors [119] and to confer migratory competence to the differentiating progenitors [108].

Foxg1-Cre-mediated Rac1 deletion severely disrupts the tangential migration of both LGE- and MGE-derived interneurons [108]. Also the Syn-Cre mediated deletion of Rac1 results in defective interneuron migration and differentiation. Interestingly, the hyperactivation of Rac1/Rac3 also affects migration, maturation and synaptogenesis of hippocampal interneurons, in similar ways [21].

Recent works have shown that Rac1 and Rac3 contribute synergistically to the development of cortical and hippocampal GABAergic interneurons [26,48]. These studies have also pointed to a possible role of Rac1 and Rac3 proteins in the later development of specific populations of MGE-derived interneurons [48] and have highlighted cytoskeletal defects in cultured MGE-derived neurons from Rac1/Rac3 double KO mice that may justify the observed migratory defects [26].

The above observations raise interesting points: The increasing role of inhibitory neurons in neurological and cognitive disorders, and the fact that we know very little about the inhibitory neurons (their subtypes, their connectivity) and in particular their synapses (organization, strength, plasticity). The focus on dendritic spines, i.e., excitatory synapses, justified by the experimental accessibility, leaves several questions unanswered, such as the role of inhibition and the plasticity of non-spiny synapses.

\subsection{Mutations of PAK3}

The p21-activated kinases (PAKs) are a Rac/cdc42-dependent family of Ser/Thr protein kinases. However, PAKs can also act upstream of Rac1 by interacting with the Rac-GEF called PAK-interacting exchange factor (PIX) [124].

In ID patients a missense mutation of $P A K 3$ gene, located on chromosome $\mathrm{Xq} 23$, was found to result in a premature termination of translation, representing a loss-of-function mutation [125,126]. Since these original observations, additional PAK3 mutations have been detected in both syndromic and non-syndromic ID [127-131], all of which appear to be loss-of-function [132].

Pak3 is expressed in the developing and adult brain, including the cortex and hippocampus $[125,133,134]$. In cultured neurons, active Pak3 is distributed throughout the cell soma and the dendritic shafts [112,133]. In vitro, PAK3 mutations affect actin dynamics at dendritic spines [132] resulting in a decreased density of spines and synapses [135].

Two mouse models have been generated. The first is a DN-Pak transgenic mice, consisting in the Pak autoinhibitory domain, which binds to the catalytic domain of group I Paks (Pak1, Pak2 and Pak3) to block their autophosphorylation and consequently the activation of their catalytic activity [112]. The second is the Pak3 KO [125]. Cortical neurons in these mice display fewer dendritic spines and an increased proportion of larger synapses. Altered synaptic morphology are correlated with enhanced LTP and reduced LTD in the cortex [112]. Notably, Pak3-deficient mice exhibit specific impairments in the consolidation/retention phase of hippocampus-dependent memories [112,133].

\subsection{Mutations of $\alpha$ PIX}

The PAK-interacting exchange factor ( $\alpha$ PIX) gene, also known as ARHGEF6 or Cool2, is located on chromosome Xq26.3, codes for a GEF active on Rac1, and can induce membrane ruffling [106,136,137]. In X-linked ID patients the $\alpha$ PIX identified mutation is in the first intron and results in preferential skipping of exon 2 predicting a protein lacking 28 amino acids [138].

Murine $\alpha$ Pix is highly expressed in the hippocampus, in the cortex and in the cerebellum, both in neuronal cell bodies and in dendrites [106]. In cultures neurons $\alpha$ Pix colocalizes with PSD-95 at the PSD of excitatory synapses [136]. The knockdown of $\alpha$ Pix results in spine morphology alterations, 
characterized by a decrease of large mushroom-type spines and an increase of elongated spines and filopodia-like protrusions [136,137].

In contrast, the absence of $\alpha$ Pix in vivo leads to a significant increase in the dendritic length and in the number of dendritic spines along apical dendrites on one side and induces a reduction in excitatory contact density in adult mice on the other side, suggesting that there are more spines that do not participate in the formation of synapses in the hippocampi of $\alpha$ Pix KO mice [106].

Similar discrepancies between in vivo and in vitro phenotypes have also been noted for Ophn1 and PAK3 $[94,99,133,135]$. It has been proposed that the cellular environment may account for the distinct phenotypic effects as the environment of neurons and spines is much more complex in vivo compared with dissociated and slice cultures.

Behavioral characterization of $\alpha$ Pix KO mice revealed largely intact performance in basic tests of spatial reference and working memory. However, these mice exhibit deficits in more complex spatial learning and flexibility, and reduced behavioral control under moderate stress, thus mimicking the human ID phenotype [106].

\subsection{Mutations of ARHGEF9}

The ARHGEF9 gene, located on chromosome Xq11.1, codes for collybistin, is a neuronal GDP-GTP exchange factor that specifically activates cdc42 and not Rac or RhoA [139]. The first mutation described is a breakpoint between exons 6 and 7 of ARHGEF9 resulting in the absence of full-length transcripts in patients with ID [140]. Subsequently, Lemke et al. [141] reported a missense mutation in the RhoGEF domain of ARHGEF9 associated with ID. Using X-chromosome exome sequencing, a novel mutation in ARHGEF9 was reported in a family with X-linked ID with variable macrocephaly and macro-orchidism [142]. One year later mutations or structural genomic alterations affecting ARHGEF9 were reported in patients with ID [143].

The mechanism by which mutations of ARHGEF9 lead to neurodevelopmental disorder is beginning to be clarified; as $\mathrm{CB}$ is involved in the formation of inhibitory GABAergic synapses, the loss-of-function mutations of ARHGEF9 lead to neuronal hyperexcitability. Furthermore, the loss of CB function is associated with reduced inhibition of mTOR [144].

During brain development, alternative ArhGEF9 mRNA splicing generates CB1 and CB2 isoforms in varying ratios. $\mathrm{CB} 1$ level is enhanced during early brain developmental, while $\mathrm{CB} 2$ levels remain constant throughout brain development [145].

In primary neurons, CB1 and CB2 differentially promote the formation of gephyrin clusters (hence, GABAergic synapses) depending on the degree of maturity of dendritic segments [145]. During hippocampal adult neurogenesis CB1 regulates neuronal migration, while CB2 is essential for dendrite outgrowth, in fact $\mathrm{CB} 2$ overexpression results in a significant reduction in complexity of the dendritic tree and reduced total and terminal dendritic length [145].

ArhGEF9 KO mice show normal locomotor performance but reduced exploratory behavior and enhanced anxiety and impaired spatial learning [115]. These behavioral findings are associated with a region-specific loss of postsynaptic gephyrin and $\mathrm{GABA}_{\mathrm{A}}$ receptor clusters in the hippocampus and the basolateral amygdala $[114,115]$. The changes in hippocampal synaptic plasticity are accompanied by increased LTP due to reduced dendritic GABAergic transmission onto CA1 pyramidal neurons [115].

\subsection{Mutations of FGD1}

The gene FGD1 (FYVE, RhoGEF and PH domain-containing protein 1), located on chromosome Xp11.22, codes for a protein which binds specifically to the GTPase cdc42 via its PH and DH domains, and stimulates the GDP-GTP exchange of its isoprenylated form [146]. FGD1 is involved in the transmission of signals that regulate the development of axons and dendrites [147]. Mutations in FGD1 have been associated with a form of syndromic X-linked ID known as the Aarskog syndrome [148] (see below) and with non-specific nonsyndromic X-linked ID [147]. 
Many missense mutations in FGD1 in either the structurally conserved region (SCR) or the pleckstrin homology domain (PHD) have been detected in syndromic X-linked ID [149]. Importantly, a base change in exon 4 , which results in proline 312 to be substituted with a leucine, is predicted to eliminate a $\beta$-turn, creating a long stretch of coiled sequence which may affect the orientations of a SH-3 binding domain and the first structural conserved region [149]. The position of the $\beta$-turn is thought to be required for the correct positioning of an AH3 domain $5^{\prime}$ to the relative SCR region $3^{\prime}$. In such way the sequence defined by exon 4 serves as a linker between the FGD1 domain. Although not experimentally verified, such mutations are expected to compromise FGD1 activity.

The microinjection of FGD1 into 3T3 fibroblasts induced actin polymerization and assembly of clustered integrin complexes [150]. Thus FGD1 is involved in the regulation of cdc42 activity at the subcortical actin cytoskeleton and Golgi complex [151].

\subsection{Mutations of TRIO}

The gene TRIO, located on chromosome 5p15.2, codes for a large protein of 3097 amino acids, member of the mammalian Dbl family. TRIO comprises two Dbl-homology-Pleckstrin-homology (DH-PH) GEF domains with distinct specificity and a C-terminal serine kinase domains [152]. The first DH-PH domain has been shown to activate Rac1 and RhoG, whereas the second activates RhoA $[153,154]$. Trio can be alternatively spliced and, as a result, encodes several isoforms whose expression is nervous system specific $[155,156]$.

An intragenic de novo $235 \mathrm{~kb}$ deletion of TRIO was detected in a boy with ID [113]. Next, targeted sequencing of this gene in over 2300 individuals with ID, identified three additional loss-of-function truncating mutations. The probands featured mild to borderline ID combined with autistic, hyperactive and/or aggressive behavior [113].

Subsequently, a heterozygous frameshift deletion and a de novo missense mutation have been reported in patients with ID associated with microcephaly [157]. The frameshift mutation results in a truncated Trio protein that is expected to be degraded by nonsense-mediated decay, thus resulting in the production of a negligible protein product. The truncated TRIO lacks the PH1 domain necessary for efficient GDP/GTP exchange [157].

Trio is highly expressed in the developing and adult brain, including the cerebellum, cortex, hippocampus and thalamus $[107,158]$. In the rat brain, Trio is expressed during the early postnatal period, but rapidly decreases later on [113]. At the cellular level, ID-associated mutations in TRIO affect dendritic branching and synapse function. Interestingly, upon suppression of endogenous TRIO both synaptic strength and dendritic formation were enhanced [113].

In the mouse, the total KO of Trio leads to embryonic lethality [159]. Neural-specific deletion of Trio leads to reduced extension of granule cell neurites and highly branched processes with perturbed stabilization of actin and microtubules; however Nestin-Trio KO mice died before reaching adulthood [107]. In order to address Trio gene function in adult mice, Emx1-Trio ${ }^{-/-}$mice have been generated; in this case Trio deletion is restricted to the cerebral cortex and hippocampus [158]. These mice show impaired hippocampal-dependent spatial learning ability, while there is no evidence that the memory is affected [158].

\subsection{Rho-GTPases and Other Neurological/Cognitive Conditions}

$R A C$ mutations have been detected in children with neurodevelopmental disorders comprising ID $[77,78]$. Depending on where the mutation on $R A C 1$ occurs, the ID phenotype was accompanied by microcephaly, macrocephaly or cerebellar abnormalities.

The $\beta$ PIX gene, also known as ARHGEF7, located on chromosome 13q34, is ubiquitously expressed in the mouse brain and codes for a cytoplasmic Rac1 GEF protein. By forming a complex with Rac1, $\beta$ PIX recruits Rac1 to membrane ruffles and to focal adhesions (see Online Mendelian Inheritance in Man (OMIM) *605477). A $1.3 \mathrm{Mb}$ deletion at 13q34, containing ARHGEF, was detected by Array Comparative Genomic Hybridization (CGH) in the genome of children with ID [160]. 
Autism spectrum disorders (ASD) is a group of conditions with a wide range of symptoms and various severity of ID. ASD have been associated with hypoactive RAC1 function [87,161,162], but also with mutations in the scaffolding molecule genes SHANK2 and SHANK3; the latter is known to modulate the activity of Rac1 and cdc42 via the GEF protein $\beta$ PIX [60]. In a separate set of ASD patients de novo mutations in TRIO have been reported [163]; these mutants tested in rodent neurons turned out to be either the hypo- or hyper-functional variant, and to result in dysregulated glutamatergic synapses. These observations underline how both and excessive or reduced TRIO activity may cause synaptic dysfunction in ASD-related pathogenesis, and point to the TRIO-Rac1 pathway at glutamatergic synapses as a possible key point of convergence of a number of ASD-related genes. In general, these findings support a role of Rho-class GTPases, and RAC1 in particular, in some of the neuropathological events associated with ASD.

Hypoactive Rac has been demonstrated in animal models of depression [164]. Transcriptional profiling of the nucleus accumbens (NAc) for Rho GTPase-related genes, revealed a sustained reduction in Rac1 expression after chronic social defeat stress. This was associated with a repressive chromatin state surrounding the Rac1 promoter. Inhibition of class 1 histone deacetylases (HDACs) rescued both the stress-induced Rac1 downregulation and the depression-related behaviors.

In a mouse model of Fragile X syndrome (FXS) the Rac1 GTPase pathway was shown to be hyperactive, causing a reduced activity of the actin-depolymerization and severing factor ADF/cofilin which in turn caused spine abnormalities [110,165]. Inhibition of the Rac1 effector PAK1 with a small-molecule inhibitor rescued ADF/cofilin signaling and synaptic signaling in FXS mice [165].

Rho-GTPases have been implicated in Alzheimer's Disease (AD) [166]. Researchers have analyzed the behavioral modifications in AD mouse models, after modifying Rho-GTPase modulations. It was found that Rac1 activity is increased in AD, while its GTPase-activating protein (GAP) $\alpha 1$-chimaerin, which acts as Rac1 inactivator, is reduced [167]. Rac1 may (con)cause neuropathogenesis of AD, since is regulates the transcription of the APP gene (Amyloid $\beta$-A4 Precursor Protein, 21q21.3, GRCh38). Notably, in primary hippocampal neurons the Rac1-specific inhibitor NSC23766 was able to decrease both Rac1 activity and APP protein levels in a concentration-dependent manner [168].

Genome analyses on families affected by Aarskog syndrome have revealed a mutation in FGD1 (R402W at position $1204(1204 \mathrm{C}>\mathrm{T}$ ) in $20 \%$ of the cases [169]. The Aarskog syndrome affects males and is characterized by short stature, craniofacial dysmorphisms, brachydactyly and urogenital abnormalities. The IQ shows a great variability, from normal to severely disabled, and no specific behavioral phenotype has been described so far, even though attention deficit and hyperactivity were observed. Studies performed by Reference [170] reported nine novel mutations (three missense mutations (p.R402Q; p.S558W; p.K748E), four truncating mutations (p.Y530X; p.R656X; c.806delC; c.1620delC), one in-frame deletion (c.2020_2022delGAG) and the first reported splice site mutation (c.1935 + 3A > C)) of FGD1, above the 20 distinct abnormalities reported until today. No phenotype-genotype correlations between type and position of mutations and clinical features were noted.

ARHGAP15 codes for a brain-specific and Rac1-specific GAP, that is able to reduce the GTP-bound level of intracellular Rac1 in the brain. Loss of ARHGAP15 has been documented in a rare variant of the Mowat-Wilson disease, which is characterized by severe neurological and cognitive deficits, autism and speech impairments [171,172]. The loss of ArhGAP15 accompanies the loss of the recognized disease gene Zeb2 [173], nonetheless ARHGAP15 might contribute to the severity of these conditions or, alternatively, could act as a modifier gene. In mice loss of ArhGAP15 results in increased Rac1/Rac3 activity, reduced spine density, reduced axonal and dendritic complexity and cognitive deficits [21,25].

The ARHGAP18 gene, expressed in the developing and adult CNS, controls cell shape and spreading, as well as neuronal motility [174] and has been linked to schizophrenia $[175,176]$. A genome wide screening strategy was applied along with neuroimaging measures and sixty-one single nucleotide polymorphisms (SNPs) variation was identified in this gene and associated to the phenotypic variation [175]. 
The gene SYNGAP1 (Synaptic RAS-GTPase activating protein1) located on chromosome 6p.21.32 codes a brain-specific Ras GTPase activating protein localized on dendritic spines in neocortical pyramidal neurons. De novo truncating mutations (K138X, R579X, and L813RfsX22) were detected in children with autosomal dominant nonsyndromic ID [177]. The mutations eliminate the domain for synaptic plasticity and spine morphogenesis and result in the usage of a premature stop codon that destabilizes the SYNGAP1 mRNA and activates nonsense-mediated decay.

Finally, altered Rac1 signaling has also been implicated in the Rett syndrome, and it may contribute to cyclin-dependent kinase-like5 (CDKL5)-related disorders [178].

\subsection{Other Mouse Models to Further Explore the ID Cellular Phenotype}

LIMKs are a downstream target for RhoA, Rac1 and cdc42, widely expressed in the mammalian CNS [179-181]. While LIMK-2 is expressed in all cell types, LIMK-1 is restricted to neuronal tissues and is enriched in mature synapses and in presynaptic terminal of adult neuromuscular junctions and in the spinal cord [182-185]. The deletion of LIMK-1 in mice lead to a reduction in the level of $\mathrm{ADF} /$ cofilin phosphorylation and an increase in its actin depolymerizing activity [109]. These mice exhibit significant abnormalities in both spines and growth cones morphology, in synaptic structure and function, including enhanced hippocampal LTP [109]. LIMK-1 ${ }^{-/}$mice show altered behavioral responses, including impaired fear conditioning and spatial learning, as indicated by a greater increase in the latency to locate a new platform position during the learning reversal phase [109].

ArhGEF2 (also known as Lfc and GEF-H1) is a Rho GEF protein, and its loss of function is associated to a neurodevelopmental disorder characterized by ID, mild microcephaly and midbrain-hindbrain malformation [51]. In the mouse, ArhGEF2 is highly expressed in cortical and hippocampus neurons, and regulates neurogenesis from cortical precursor cells [186,187]. Cultured hippocampal neurons overexpressing ArhGEF2 exhibit a greatly reduced dendritic tree with fewer arborizations, decreased spine length and spine area, but increased spine density [187]. The role of ArhGEF2 in vivo has not been reported.

ArhGAP12 is a RhoGAP that negatively regulates Rac1 signaling [188]. ArhGAP12 is expressed in the hippocampal CA1 region and to a lesser extent in the dentrate gyrus, the protein is detected in the postsynaptic compartment of excitatory synapses of hippocampal CA1 pyramidal neurons [188]. The overexpression of ArhGAP12 in organotypic hippocampal slices caused a decrease in both spine density and volume, and an increase in immature spines [188], while its silencing resulted in a reduced density of immature spines [188]. At the synaptic level, ArhGAP12 overexpression significantly depresses AMPAR- and NMDAR-mediated synaptic transmission, while its downregulation resulted in potentiation of AMPAR-mediated but not NMDAR-mediated transmission [188]. In CA1 pyramidal neurons silencing of ArhGAP12 largely increases both frequency and amplitude of mEPSCs, but had no effect in evoked IPSCs [188]. No differences are observed in presynaptic release [188]. The role of ArhGAP12 in vivo has not been reported.

\subsection{Specificity of the Rho vs. Rac vs. cdc42 Pathways}

Table 2 summarizes the current knowledge on the specificity of the GAPs and GEFs implicated in ID with respect to RhoA, Rac and cdc42. The GAP activity of OPHN1 appears not to be fully specific for RhoA, but to extend to Rac and cdc42 [90]. OPHN1 appears to be mainly active to downmodulate the RhoA/Rho-kinase signaling pathway, repressing its inhibitory activity on endocytosis and actin-myosin contractility [100]. In fact, the inhibition of RhoA and/or ROCK in Ophn-mutant mice partially corrects their deficits, thus large part of the ID phenotypes appear to be linked to the hyperactivation of the RhoA/ROCK pathway. The TRIO protein appears to be a GEF for both RhoA, RhoG and Rac1 [153,154], thus its mutations is expected to affect both pathways.

In summary, mutational studies have led to the identification of a number of genes coding for small GTPases of the Rho-class (RAC1) or their regulatory proteins (GAPs and GEFs), or their target proteins (PAK, LIMK), whose mutation leads to, or are closely linked to, ID. The currently available 
knowledge converges to indicate a causative role of hyperactive RhoA pathway and, conversely, hypoactive Rac1 and cdc42 pathways, for the onset of the ID condition.

Mutations directly affecting the small GTPase pathway still account only for a fraction of the total cases of ID, for which the cause remains unknown. Perhaps combinations of disease-associated alleles, each representing only a minor risk factor, will explain some of the remaining (majority) of cases. Whether small GTPases are indirectly involved (i.e., functionally hypoactive for other reasons) in ID in the absence of mutations in known ID genes, is currently unclear.

Altered activity of the Rac1 GTPase is likely to be a common denominator for several neurodevelomental conditions which include an ID component, regardless of whether the genetic cause(s) has been identified. This is not surprising, since these disorders are characterized by altered synaptic plasticity and aberrant spine morphology and density, processes that are regulated by small Rho-GTPases (e.g., [189]). The possibility to finely and specifically remodulate Rac1 activity could have a much wider clinical perspective then those forms of ID caused by Rac1-pathway mutations. 
Table 2. GTPase specificity of genes involved in human ID.

\begin{tabular}{|c|c|c|c|c|c|c|}
\hline Gene Mutated in ID & Location & Mutation & Functional Effect ${ }^{(1)}$ & GTPase Specificity & Function & References \\
\hline Oligophrenin1 (OPHN1) & Xq12 & $\begin{array}{l}(\mathrm{X} ; 12)(\mathrm{q} 11 ; \mathrm{q} 15) \text { translocation } \\
\text { 1-bp deletion }\end{array}$ & LoF & Mainly RhoA & $\begin{array}{l}\text { Repression of Rho-kinase pathway } \\
\text { Control of endocytosis } \\
\text { Control of actin-myosin contractility }\end{array}$ & Barresi et al. 2014 [100] \\
\hline p21 Protein Activated Kinase (PAK3) & Xq23 & Missense (R67C) & LoF & Rac1 and cdc42 & $\begin{array}{l}\text { Dendrite development } \\
\text { Dendritic spine maturation and } \\
\text { synaptic plasticity }\end{array}$ & $\begin{array}{l}\text { Ncbi gene ID } 5063 \\
\text { RefSeq } 2018 \\
\text { Allen et al., } 1998 \text { [125] } \\
\text { Bienvenu et al., 2000 [126] }\end{array}$ \\
\hline $\begin{array}{l}\text { RHO Guanine Nucleotide Exchange } \\
\text { Factor } 6 \text { (ARHGEF6, } \alpha \text { PIX) }\end{array}$ & Xq26.3 & IVS1-11T $\rightarrow C$ & Exon 2 skipping (LoF) & Rac1 and cdc42 & Induction of membrane ruffling & $\begin{array}{l}\text { OMIM \#300267 } \\
\text { Ramarkers et al., } 2012 \text { [106] } \\
\text { Kutsche et al., } 2000 \text { [138] }\end{array}$ \\
\hline $\begin{array}{l}\text { RHO Guanine Nucleotide Exchange } \\
\text { Factor } 9 \text { (ARHGEF9) }\end{array}$ & Xq11.1 & $\begin{array}{l}\text { Breakpoint betwee nexon } 6 \text { and } 7 \\
\text { p.R290H missense mutation } \\
\text { c1012C > T; p.R338W }\end{array}$ & $\begin{array}{l}\text { Absence of full-lenght } \\
\text { transcripts (LoF) }\end{array}$ & cdc42 & $\begin{array}{l}\text { Recruitment of gephryn and receptors in } \\
\text { GABAergic and glycinergic synapses }\end{array}$ & $\begin{array}{l}\text { Ncbi gene ID } 23229 \\
\text { Kalscheuer et al. } 2009 \text { [140] } \\
\text { Lemke et al., } 2012 \text { [141] }\end{array}$ \\
\hline $\begin{array}{l}\text { FYVE, RhoGEF and PH } \\
\text { Domain-Containing Protein } 1 \text { (FGD1) }\end{array}$ & Xp11.22 & C934T exon 4 & $\begin{array}{l}\text { Elimination of } \\
\text { a } \beta \text {-turn (LoF) }\end{array}$ & cdc42 & $\begin{array}{l}\text { Axon and dendrite outgrowth } \\
\text { and complexity }\end{array}$ & $\begin{array}{l}\text { Zheng et al. } 1996 \text { [146] } \\
\text { Martinez-Castellano 2006 [147] } \\
\text { Lebel et al., 2002 [149] }\end{array}$ \\
\hline Triple Functional Domain (TRIO) & $5 \mathrm{p} 15.2$ & $\begin{array}{l}\text { De novo } 235 \text { kb deletion } \\
\text { p.Arg217**, p.Asp1231Valfs*11 } \\
\text { p.Trp1376* } \\
\text { Frameshift deletion } \\
\text { (pGln1489Argfs*11) } \\
\text { De novo missense mutation } \\
\text { (p.Arg1428Gln, p.Pro1461Thr, } \\
\text { p.Asn1080Ile) }\end{array}$ & LoF & Rac1, RhoG, RhoA & $\begin{array}{l}\text { Axon guidance } \\
\text { Neurite outgrowth } \\
\text { Cerebellum development }\end{array}$ & $\begin{array}{l}\text { Blangy et al. } 2000 \text { [154] } \\
\text { Jaiswal et al. } 2013 \text { [153] } \\
\text { Pengelly et al. . } 2016 \text { [157] } \\
\text { Ba et al., } 2016 \text { [113] }\end{array}$ \\
\hline $\begin{array}{l}\text { Rho Guanine Nucleotide Exchange } \\
\text { Factor } 7 \text { (ARHGEF7, } \beta \text {-PIX) }\end{array}$ & $13 q 34$ & $1.3 \mathrm{Mb}$ deletion at $13 \mathrm{q} 34$ & LoF & Rac1 & $\begin{array}{l}\text { Increase of synaptic Rac activity } \\
\text { Increase of dendrite protrusions } \\
\text { Induction of membrai nruffling }\end{array}$ & $\begin{array}{l}\text { Ncbi gene ID } 8874 \\
\text { Orsini et al., } 2018 \text { [160] }\end{array}$ \\
\hline $\begin{array}{l}\text { Ras-Related C3 Botulinum Toxin } \\
\text { Substrate } 1 \text { (RAC1) }\end{array}$ & $7 \mathrm{p} 22.1$ & $\begin{array}{l}\text { c53.G > A (pCys18Tyr) } \\
\text { c116A > G (pAsn39Ser) }\end{array}$ & $\mathrm{DN}$ & & $\begin{array}{l}\text { Modulation of the cytoskeleton } \\
\text { Control on cell growth } \\
\text { Control on cell-cycle }\end{array}$ & $\begin{array}{l}\text { OMIM \#602048 } \\
\text { Lelieveld et al., } 2017 \text { [77] } \\
\text { Rejinders et al., } 2017 \text { [78] }\end{array}$ \\
\hline
\end{tabular}

(1) Abbreviations: LoF, Loss of Function; DN, Dominant Negative. 


\section{Cognitive Deficits Due to Developmental Miswiring Can Be Reverted}

For a long time, the prevailing view has been that ID and neurodevelopmental disorders in general cannot be cured because the defective cellular processes are difficult to target and to be rescued. Such is perhaps the case of altered neurogenesis and long-distance connections. Much of the treatment has therefore focused on environmental optimization, including individualized education plans, as well as minimizing complicating co-morbidities (such as, visual, sleep or pain co-morbidities) [190]. For specific syndromes associated with ID, therapeutic strategies are known [190]. For instance, for some metabolic disorders, such as Pompe disease, enzyme replacement therapy is used, which can drastically change prognosis and is sometimes accompanied by intellectual sparing.

It is becoming increasingly clear, on the contrary, that errors in local circuitry, neuronal networking and synaptic physiology/plasticity can be partially reverted to a more normal architecture and functioning, accompanied by improvements in cognitive performances, upon correction of the underlying molecular or biochemical defect. This is due to the surprisingly high intrinsic plasticity of short-range projections and synaptic number, position and strength. Although reduced compared to the embryonic and newborn brain, adult local neural circuits are still able to undergo some extent of reorganization and to balance excitatory vs inhibitory activity. Following some notable examples:

\subsection{Gene Therapy of Rett Syndrome}

Rett syndrome is a severe progressive condition comprising ID, due to mutations in the X-linked MECP2 gene. Mecp2 $\mathrm{B}^{\text {null/- }}$ female mice are a widely used model of Rett syndrome [191]. A normal copy of the Mecp 2 cDNA was placed under control of a fragment of its own promoter into scAAV9 vector and tail-vein injected into young adult $M e C P 2$ null mice. Widespread delivery of MeCP2 was observed, the exogenous MeCP2 protein was found to be functional and able to bind to heterochromatin. Delivery of exogenous MeCP2 restored normal neuronal size and morphology. Strikingly, by 12 weeks and up to 24 weeks, several Rett-associated parameters (including mobility, gait, hindlimb clasping, tremor and general condition) stabilized at an improved level in the scAAV9/MeCP2-injected MeCP2B $\mathrm{B}^{\text {null/- }}$ females, whereas control injected females progressed. MeCP2-injected Mecp $2 \mathrm{~B}^{\text {null } /-}$ mice performed significantly better than controls in the rotarod, inverted grid, and platform tests as well as nesting ability [192]. Thus, gene replacement strategies are effective in reversing the neurological deficits of Rett syndrome.

\subsection{Channel Therapy for Down Syndrome}

The Ts65Dn mice represent the best characterized and mostly used animal model of Down syndrome $[193,194]$. They recapitulate key hippocampal cognitive deficits of the human syndrome, such as impaired synaptic plasticity, long term potentiation (LTP), learning and memory deficits, and increased generation of forebrain GABAergic interneurons. The latter is believed to lead to imbalanced excitatory/inhibitory transmission in favor of inhibition $[195,196]$, which affects synaptic plasticity and cognition [197,198].

$\mathrm{GABA}_{A} \mathrm{R}$ signaling was found to be excitatory rather than inhibitory in Ts65Dn mice. This excitatory activity was accompanied by (i) a shift in the reversal potential for $\mathrm{GABA}_{\mathrm{A}} \mathrm{R}$-driven $\mathrm{Cl}^{-}$ currents $(E C l)$ toward more positive potentials and (ii) increased hippocampal expression of the cation $\mathrm{Cl}^{-}$cotransporter NKCC1 in both Ts65Dn mice and individuals with Down syndrome. The treatment of adult Ts65Dn mice with the FDA-approved NKCC1 inhibitor bumetanide restored $E C l$ to potentials seen in normal mice and rescued both synaptic plasticity and hippocampus-dependent memory [199].

The above observations provide the scientific framework to justify attempts to re-modulate the Rho-GTPases activity and revert the associated neurological and cognitive conditions. Research is increasing in this direction, and it is now clear that re-modulation of the Rho-GTPase pathways impacts on neuronal and synaptic networking also in young adults, both in normal conditions and in pathological contexts. Research on ID, however, is still lagging behind for a number of reasons: First, with the exception 
of the rare inherited forms, the molecular causes are multiple and variable, possibly polygenic and possibly due to complex and unclear gene-environment interactions; second, it is often syndromic i.e., associated to other neurological disturbances; third, the actual endophenotype associated to nonsyndromic ID in human is unknown, only inferred from mouse models; fourth, (as consequence of the three previous ones) we lack suitable cell models, based on human neurons, that reliably recapitulated some of the endophenotypes of ID in the human cortex.

The administration of bacterial Cytotoxic Necrotizing Factor 1 (CNF1), a known GTPase-activating molecule, to normal mice elicited an increased neuronal connectivity via dendritic spine remodeling $[33,200]$. The same treatment applied to a mouse model of Alzheimer's Disease (AD) was able to revert some of the behavioral deficits [201]. However, the activity of CNF1 is poorly characterized, and does not discriminate between members of the Rho GTPase family.

The administration of fasudil, an inhibitor of the ROCK and PKA kinase pathways, improved spatial learning and working memory in normal mice and rats [202,203]. Considering that fasudil is safe and well tolerated, and has also been approved for human treatment [204-206] to target the CNS [207], it could potentially be used to restore normal cognitive performances in those pathologies linked to RhoA hypoactivity.

\subsection{Remodulation of RhoA in the Ophn KO Mouse}

Hyperactive RhoA pathway due to loss of $O P H N$ is the biochemical cause of the complex neuronal phenotypes leading to a XLID (see above). Y-27632 is an inhibitor of the RhoA-dependent kinase ROCK. Treatment of hippocampal slices from Ophn-1-/y mutant brains with Y-27632 was able to reverse the synaptic deficits observed in mutant neurons and, on a slower time scale, also the altered dendritic structure $[98,101]$. A notable feature of this treatment is that it had no effect on WT neurons. The brain penetration of Y-27632 was thought to be too low to achieve therapeutic levels for CNS diseases [208], instead several studies have shown beneficial effects of Y-27632 treatment in animal models of neurodegenerative diseases [209-211].

In addition to RhoA/ROCK pathway, in some regions of the $O p h n 1^{-/ y}$ brain increased activity of the Protein Kinase A (PKA) pathway was also detected [98,212]. Fasudil is a compound that is able to inhibit both ROCK and PKA kinases activities. The oral administration of fasudil to adult Ophn1-/y mice was able to rescue some of their memory deficits [98]. In a more extensive study, the effect of chronic oral administration of fasudil to adult $O p h n-1^{-/ y}$ on behavioral and cognitive activities, as well as neuronal and synaptic properties, was examined [213]. The treatment was able to counteract vertical and horizontal hyperactivities, to restore recognition memory, while it had little or no effect on working and spatial memory deficits. The reduced beneficial effect on memory performance suggests that not all neurodevelopmental alterations may be compensated for by treatments at the adult stage. In alternative, it has been proposed that administration of drugs such as antidepressant prior to fasudil could lead to higher efficacy due to their ability to reactivate the juvenile plasticity in the adult brain $[214,215]$. Globally these results highlight the potential of fasudil treatment in synaptopathies and also the need for multiple therapeutic approaches especially in adult where plasticity is reduced.

Allegra et al. [216] examined the survival, axonogenesis and spinogenesis of hippocampal neurons of Ophn-1 $1^{-/ y}$ mice upon treatment with fasudil. In Ophn-1-/y mice a deficit in neuronal survival has been observed in newborn animals, while proliferation of stem/progenitor cells appears normal. Fasudil treatment was able to increase the number of mature newborn neurons in Ophn-1-1y mice, thus the inhibition of ROCK/PKA may overcome the deficits caused by Ophn1 mutation at an early stage of neuronal maturation. The same authors found altered morphological maturation of newly generated cells with a robust impairment of axonal extension and immature dendritic spines in Ophn-1-1y mice. In this context, fasudil corrected the dendritic spine deficit 21 days after injection, but was unable to restore a normal proportion of newborn neurons projecting the CA3 area. Altogether, the morphological analysis reveals two key processes impacted by Ophn1 deficiency: Axonal extension and dendritic spine morphogenesis, both of which are critical for proper integration 
of newborn neurons. The fasudil rescue experiments indicate that these two processes proceed via at least partly independent pathways: Dendritic spine density can be restored by downregulating abnormally high ROCK/PKA activity in Ophn-1-/y mice, while the same approach is not effective on aberrant axonogenesis.

\subsection{Remodulation RhoA in Mouse Model of Rett Syndrome}

Positive remodulation of brain Rho GTPases by CNF1 reshapes the actin cytoskeleton and enhances neurotransmission and synaptic plasticity in mouse brains. Indeed a single CNF1 Intracerebroventricular injection (icv) inoculation of CNF1 in a mouse model of Rett syndrome markedly improved the behavioral phenotype of MeCP2-308 mice [217]. CNF1 also dramatically reversed the evident signs of atrophy in astrocytes of mutant mice and restored wt-like levels of this cell population [217]. These results indicate that remodulation of Rho-class GTPases by CNF1 may constitute a totally innovative therapeutic approach for RTT and, possibly, for other disorders associated with ID.

Increasing evidence suggest that mitochondrial dysfunction [218] and deviations from normal Rho GTPases activation state [219] disrupt cognition and synaptic plasticity and may represent important factors in the cellular pathogenesis of ID, including the Rett syndrome. De Filippis et al. [88] achieved a re-activation of Rho GTPases by icv administration of CNF1 to adult Mecp2-308 heterozygous female mice. They observed a restored mitochondrial ATP production via oxidative phosphorylation, accompanied by the rescue of deficits in spatial reference memory, synaptic plasticity (LTP) and Tyr1472 phosphorylation of GluN2B, which was abnormally enhanced in the hippocampus of Rett model mice [88]. This study provides the first evidence that these brain alterations may be intimately interconnected, thus providing further support to the therapeutic potential of drugs targeting Rho GTPases and their downstream effectors.

\subsection{Remodulation of Rac1}

Rac1 activity is dysregulated in certain neurodevelopmental disorders that present all these three alterations: ID, atypical synaptic plasticity and aberrant spine morphology (see above). Thus, to develop novel therapies for rescuing cognitive impairment, a reasonable approach might be to target Rac1 or its direct regulators.

Modulation of Rac1 activity using chemical inhibitors might be a strategy to reestablish cognitive function. Drugs that regulate Rac1 activation and function could be used to modulate actin cytoskeleton and spine dynamics, representing potential candidates to alleviate the ID condition, whether alone on as part of other disorders associated with spine abnormalities.

Several compounds have been described as Rac1-specific inhibitors [87] including NSC23766, EHop-016, AZA1 and EHT1864. The initial strategy for the identification of these compounds has been primarily based in the information on structure-function of Rac1 interacting with its GEFs [220]. These inhibitors have mainly been tested in models of cancer metastatization, in vitro and in vivo, attempting to inhibit tumor cell migration [87]. Indeed, an elevated level and hyperactivation of Rac1 has been associated with the metastatic potential of tumor cells [221].

Little research has been done on the possibility to inhibit the activity of Rac in the CNS. NSC23766 acts as Rac1 inhibitor interfering with specific Rac1-GEFs, Trio and Tiam-1, thus blocking GDP/GTP exchange [222]. Many in vivo and in vitro studies have reported its efficacy in neuronal cells affecting dendritic spine morphology, thus increasing the number of immature spines [223]. Moreover, Zhang et al. [224] have reported a change in neuronal spine density in the rat hippocampus treated with NSC23766. Interestingly, the inhibition of Rac1-associated signaling by NSC23766 has been shown to be involved in extinction of memory [225]. The use of NSC23766 as a therapeutic agent is discouraged due to its high IC50.

EHT1864 selectively inhibits Rac1 downstream signaling by affecting the displacement of GTP. In this manner, Rac1 remains in an inactive state, as Rac1-GDP. In vitro experiments demonstrate that 
treatment with EHT1864 reduces NMDAR density in rat cortical cultures [226] and decreases density of dendritic spines in coltured hippocampal pyramidal neurons [227]. Further in vivo analysis need to be performed to confirm EHT1864 as a potential therapeutic agent.

The pharmacological regulation of Rac1 in the brain can be effective to restore some of the cellular phenotype underlying ID. However, the available molecules primarily act on the Rac1-downstream pathway without any tissue-specificity and it is overtly clear that the cytoskeleton coordinates a wide number of processes, such as proliferation, morphogenesis and motility, that are finely regulated in every type of cells. Thus, targeting Raclin this way, in the entire organism to improve cognitive functions may reasonably cause relevant side effects.

As illustrated above, ID and disorders such as ASD which frequently include ID, are consistently characterized by reduced (but not absent) activity of the Rac1 and cdc42 pathways, as opposed to increased RhoA activity (Tables 1 and 2). This raises the interest to identify positive Rac1 and cdc42 modulators. A re-activation strategy is feasible in those cases in which a quote of Rac1 or cdc42 enzyme is still present in the diseased neurons. Specifically, (a) in the case of heterozygous RAC1 mutations, the remaining normal quote of endogenous RAC1 can be exploited [78]; (b) in the case of ARHGEF6 mutations, a normal quote of endogenous RAC1 is still present; (c) mutations in ARHGEF9, FGD and TRIO, all of which are upstream of Rac1 and cdc42, alter GTPase activity in the presence of normal Rac1 and cdc42. Only the PAK3 mutations might not to be reverted by Rac1 reactivation.

Interfering with protein:protein interaction (PPI) between GTPase and its GEF is expected to result in their down-modulation [222] while interfering with PPI between GTPase and its GAP is expected to result in their up-modulation [21]. A new generation of Rac1 inhibitors is emerging, identified via structural modelling of the Tiam::Rac1 PPI, which turn out to be effective and selective [228]. In a similar way, PPI between Rac1 and its specific GAPs could be exploited to design peptide or virtual screen for small molecules [229]. Notably, ArhGAP15 is a brain specific, Rac1-specific GAP which modulates by 2 -folds neuronal Rac1 activity [21,230]. Clearly, the specific activity and function of each GAP and GEF in brain development is only partly known, and intense research is needed in this direction.

\section{Concluding Remarks}

Treatments of ID are currently based on environmental optimization and personalized education plans, as well as minimizing complicating co-morbidities. Pharmacotherapy is substantially lacking. Recent evidence suggests that some phenotypes associated with learning disabilities can be reversed, through either genetic correction or pharmacotherapy. At present, whether these provide a realistic opportunity for treatment remains to be proven.

Rho GTPases are a good target for pharmacological intervention, and in specific conditions with genetic mutations causing hyperactive Rho or hypoactive Rac pathways, these would need to be negatively or positively re-modulated, respectively. To achieve brain-specific, GTPase-specific, modest and controlled re-modulation, the PPI between GTPases and their GEFs and GAPs regulatory partners open a promising window of opportunity. However, the role of each of these regulators would need to be defined, in biochemical, cellular and developmental terms. Importantly, novel druggable targets might be identified from studies focusing on the extended protein network linked to Rho GTPases during cell migration and/or neuritogenesis (see [231,232]).

The knowhow needed to identify remodulating compounds based on PPI is here: Structural information on GTPases, GAPs and GEFs, advanced protein-docking tools, effective techniques for peptide design and virtual screens. Thus, taking in account the feature of this type of interaction, PPI-based design of peptides or small molecules seems a most promising strategy, in order: (1) to be tissue-specific; (2) to be GTPase-specific; (3) to achieve mild and finely tuned over- and under-activation.

Translation to the human setting will require the generation and validation of cellular models of ID based on human neurons, that ideally should consent the analysis of both excitatory and inhibitory 
neurons, and should recapitulate the ID endophenotype. The use of human iPSC seems to be the way to go. Having such a model in hand, this will be used to better define the cellular phenotype of ID in human cells, to identify valuable readouts for a possible correction, and to carry out screening campaigns towards the identification of lead compounds that alleviate ID.

Author Contributions: V.Z., R.J., A.U., A.A. wrote parts of the original text. V.Z. assisted in the figure design. M.P., E.H. and G.R.M. coordinated the writing, outlined and revised the manuscript.

Funding: This research received no external funding.

Acknowledgments: We thank Gaia Berto, Ferdinando DiCunto and Paola DeFilippi (University of Torino) for critical reading of the manuscript.

Conflicts of Interest: The authors declare no conflict of interest.

\section{Abbreviations}

$\begin{array}{ll}\text { ASD } & \text { Autism Spectrum Disorder } \\ \text { CA } & \text { Constitutively active } \\ \text { DN } & \text { Dominant negative } \\ \text { GAP } & \text { GTPase Activating Protein } \\ \text { GEF } & \text { Guanosine Exchange Factor } \\ \text { GTPase } & \text { Guanosine Tri-phosphate Phosphatase } \\ \text { ID } & \text { Intellectual Disability } \\ \text { KD } & \text { Knockdown } \\ \text { KO } & \text { Knockout } \\ \text { PPI } & \text { Protein::Protein Interaction } \\ \text { PSD } & \text { Postsynaptic Density } \\ \text { XLID } & \text { X-linked Intellectual Disability }\end{array}$

\section{References}

1. Azzarelli, R.; Kerloch, T.; Pacary, E. Regulation of cerebral cortex development by Rho GTPases: Insights from in vivo studies. Front. Cell. Neurosci. 2015, 8, 445. [CrossRef] [PubMed]

2. Heasman, S.J.; Ridley, A.J. Mammalian Rho GTPases: New insights into their functions from in vivo studies. Nat. Rev. Mol. Cell Biol. 2008, 9, 690-701. [CrossRef] [PubMed]

3. Govek, E.E.; Hatten, M.E.; Van Aelst, L. The role of Rho GTPase proteins in CNS neuronal migration. Dev. Neurobiol. 2011, 71, 528-553. [CrossRef] [PubMed]

4. Hall, A.; Lalli, G. Rho and Ras GTPases in axon growth, guidance, and branching. Cold Spring Harb. Perspect. Biol. 2010, 2, a001818. [CrossRef] [PubMed]

5. O'Donnell, M.; Chance, R.K.; Bashaw, G.J. Axon Growth and Guidance: Receptor Regulation and Signal Transduction. Annu. Rev. Neurosci. 2009, 32, 383-412. [CrossRef] [PubMed]

6. Rico, B.; Beggs, H.E.; Schahin-Reed, D.; Kimes, N.; Schmidt, A.; Reichardt, L.F. Control of axonal branching and synapse formation by focal adhesion kinase. Nat. Neurosci. 2004, 7, 1059-1069. [CrossRef] [PubMed]

7. Cho, S.Y.; Klemke, R.L. Purification of pseudopodia from polarized cells reveals redistribution and activation of Rac through assembly of a CAS/Crk scaffold. J. Cell Biol. 2002, 156, 725-736. [CrossRef] [PubMed]

8. Brugnera, E.; Haney, L.; Grimsley, C.; Lu, M.; Walk, S.F.; Tosello-Trampont, A.-C.; Macara, I.G.; Madhani, H.; Fink, G.R.; Ravichandran, K.S. Unconventional Rac-GEF activity is mediated through the Dock180-ELMO complex. Nat. Cell Biol. 2002, 4, 574-582. [CrossRef] [PubMed]

9. Côté, J.-F.; Vuori, K. Identification of an evolutionarily conserved superfamily of DOCK180-related proteins with guanine nucleotide exchange activity. J. Cell Sci. 2002, 115, 4901-4913. [CrossRef] [PubMed]

10. Woo, S.; Gomez, T.M. Rac1 and RhoA promote neurite outgrowth through formation and stabilization of growth cone point contacts. J. Neurosci. 2006, 26, 1418-1428. [CrossRef] [PubMed]

11. Vicente-Manzanares, M.; Choi, C.K.; Horwitz, A.R. Integrins in cell migration-The actin connection. J. Cell Sci. 2009, 122, 199-206. [CrossRef] [PubMed]

12. Tolias, K.F.; Duman, J.G.; Um, K. Control of synapse development and plasticity by Rho GTPase regulatory proteins. Prog. Neurobiol. 2011, 94, 133-148. [CrossRef] [PubMed] 
13. Gomez, T.M.; Zheng, J.Q. The molecular basis for calcium-dependent axon pathfinding. Nat. Rev. Neurosci. 2006, 7, 115-125. [CrossRef] [PubMed]

14. Henley, J.; Poo, M. Guiding neuronal growth cones using Ca2+ signals. Trends Cell Biol. 2004, 14, 320-330. [CrossRef] [PubMed]

15. Jin, M.; Guan, C.; Jiang, Y.; Chen, G.; Zhao, C.; Cui, K.; Song, Y.; Wu, C.; Poo, M.; Yuan, X. Ca2+-dependent regulation of rho GTPases triggers turning of nerve growth cones. J. Neurosci. 2005, 25, 2338-2347. [CrossRef] [PubMed]

16. Gomez, T.M.; Letourneau, P.C. Actin dynamics in growth cone motility and navigation. J. Neurochem. 2014, 129, 221-234. [CrossRef] [PubMed]

17. Shamah, S.M.; Lin, M.Z.; Goldberg, J.L.; Estrach, S.; Sahin, M.; Hu, L.; Bazalakova, M.; Neve, R.L.; Corfas, G.; Debant, A.; et al. EphA receptors regulate growth cone dynamics through the novel guanine nucleotide exchange factor ephexin. Cell 2001, 105, 233-244. [CrossRef]

18. Niederöst, B.; Oertle, T.; Fritsche, J.; McKinney, R.A.; Bandtlow, C.E. Nogo-A and myelin-associated glycoprotein mediate neurite growth inhibition by antagonistic regulation of RhoA and Rac1. J. Neurosci. 2002, 22, 10368-10376. [CrossRef] [PubMed]

19. Swiercz, J.M.; Kuner, R.; Behrens, J.; Offermanns, S. Plexin-B1 directly interacts with PDZ-RhoGEF/LARG to regulate RhoA and growth cone morphology. Neuron 2002, 35, 51-63. [CrossRef]

20. Sarmiere, P.D.; Bamburg, J.R. Regulation of the neuronal actin cytoskeleton by ADF/cofilin. J. Neurobiol. 2004, 58, 103-117. [CrossRef] [PubMed]

21. Zamboni, V.; Armentano, M.; Sarò, G.; Ciraolo, E.; Ghigo, A.; Germena, G.; Umbach, A.; Valnegri, P.; Passafaro, M.; Carabelli, V.; et al. Disruption of ArhGAP15 results in hyperactive Rac1, affects the architecture and function of hippocampal inhibitory neurons and causes cognitive deficits. Sci. Rep. 2016, 6, 34877. [CrossRef] [PubMed]

22. Toriyama, M.; Kozawa, S.; Sakumura, Y.; Inagaki, N. Conversion of a signal into forces for axon outgrowth through Pak1-mediated shootin1 phosphorylation. Curr. Biol. 2013, 23, 529-534. [CrossRef] [PubMed]

23. Govek, E.E.; Newey, S.E.; Van Aelst, L. The role of the Rho GTPases in neuronal development. Genes Dev. 2005, 19, 1-49. [CrossRef] [PubMed]

24. Shimada, T.; Toriyama, M.; Uemura, K.; Kamiguchi, H.; Sugiura, T.; Watanabe, N.; Inagaki, N. Shootin1 interacts with actin retrograde flow and L1-CAM to promote axon outgrowth. J. Cell Biol. 2008, 181, 817-829. [CrossRef] [PubMed]

25. Zamboni, V.; Armentano, M.; Berto, G.; Ciraolo, E.; Ghigo, A.; Garzotto, D.; Umbach, A.; DiCunto, F.; Parmigiani, E.; Boido, M.; et al. Hyperactivity of Rac1-GTPase pathway impairs neuritogenesis of cortical neurons by altering actin dynamics. Sci. Rep. 2018, 8, 7254. [CrossRef] [PubMed]

26. Tivodar, S.; Kalemaki, K.; Kounoupa, Z.; Vidaki, M.; Theodorakis, K.; Denaxa, M.; Kessaris, N.; de Curtis, I.; Pachnis, V.; Karagogeos, D. Rac-GTPases Regulate Microtubule Stability and Axon Growth of Cortical GABAergic Interneurons. Cereb. Cortex 2015, 25, 2370-2382. [CrossRef] [PubMed]

27. Kawauchi, T.; Chihama, K.; Nabeshima, Y.; Hoshino, M. The in vivo roles of STEF/Tiam1, Rac1 and JNK in cortical neuronal migration. EMBO J. 2003, 22, 4190-4201. [CrossRef] [PubMed]

28. Hedman, A.C.; Smith, J.M.; Sacks, D.B. The biology of IQGAP proteins: Beyond the cytoskeleton. EMBO Rep. 2015, 16, 427-446. [CrossRef] [PubMed]

29. Palazzo, A.F.; Joseph, H.L.; Chen, Y.J.; Dujardin, D.L.; Alberts, A.S.; Pfister, K.K.; Vallee, R.B.; Gundersen, G.G. Cdc42, dynein, and dynactin regulate MTOC reorientation independent of Rho-regulated microtubule stabilization. Curr. Biol. 2001, 11, 1536-1541. [CrossRef]

30. Wittmann, T.; Waterman-Storer, C.M. Cell motility: Can Rho GTPases and microtubules point the way? J. Cell Sci. 2001, 114, 3795-3803. [PubMed]

31. Cappello, S. Small Rho-GTPases and cortical malformations: Fine-tuning the cytoskeleton stability. Small GTPases 2013, 4, 51-56. [CrossRef] [PubMed]

32. Luo, L. Rho GTPases in neuronal morphogenesis. Nat. Rev. Neurosci. 2000, 1, 173-180. [CrossRef] [PubMed]

33. Martino, A.; Ettorre, M.; Musilli, M.; Lorenzetto, E.; Buffelli, M.; Diana, G. Rho GTPase-dependent plasticity of dendritic spines in the adult brain. Front. Cell. Neurosci. 2013, 7, 62. [CrossRef] [PubMed]

34. Sawada, M.; Ohno, N.; Kawaguchi, M.; Huang, S.-H.; Hikita, T.; Sakurai, Y.; Bang Nguyen, H.; Quynh Thai, T.; Ishido, Y.; Yoshida, Y.; et al. PlexinD1 signaling controls morphological changes and migration termination in newborn neurons. EMBO J. 2018, 37, e97404. [CrossRef] [PubMed] 
35. Hikita, T.; Ohno, A.; Sawada, M.; Ota, H.; Sawamoto, K. Rac1-mediated indentation of resting neurons promotes the chain migration of new neurons in the rostral migratory stream of post-natal mouse brain. J. Neurochem. 2014, 128, 790-797. [CrossRef] [PubMed]

36. Hordijk, P.L. Regulation of NADPH Oxidases: The Role of Rac Proteins. Circ. Res. 2006, 98, 453-462. [CrossRef] [PubMed]

37. Daugaard, M.; Nitsch, R.; Razaghi, B.; McDonald, L.; Jarrar, A.; Torrino, S.; Castillo-Lluva, S.; Rotblat, B.; Li, L.; Malliri, A.; et al. Hace1 controls ROS generation of vertebrate Rac1-dependent NADPH oxidase complexes. Nat. Commun. 2013, 4, 2180. [CrossRef] [PubMed]

38. Iwasato, T.; Katoh, H.; Nishimaru, H.; Ishikawa, Y.; Inoue, H.; Saito, Y.M.; Ando, R.; Iwama, M.; Takahashi, R.; Negishi, M.; et al. Rac-GAP alpha-chimerin regulates motor-circuit formation as a key mediator of EphrinB3/EphA4 forward signaling. Cell 2007, 130, 742-753. [CrossRef] [PubMed]

39. Shi, L.; Fu, W.-Y.; Hung, K.-W.; Porchetta, C.; Hall, C.; Fu, A.K.Y.; Ip, N.Y. Alpha2-chimaerin interacts with EphA4 and regulates EphA4-dependent growth cone collapse. Proc. Natl. Acad. Sci. USA 2007, 104, 16347-16352. [CrossRef] [PubMed]

40. Estrach, S.; Schmidt, S.; Diriong, S.; Penna, A.; Blangy, A.; Fort, P.; Debant, A. The Human Rho-GEF trio and its target GTPase RhoG are involved in the NGF pathway, leading to neurite outgrowth. Curr. Biol. 2002, 12, 307-312. [CrossRef]

41. DeGeer, J.; Kaplan, A.; Mattar, P.; Morabito, M.; Stochaj, U.; Kennedy, T.E.; Debant, A.; Cayouette, M.; Fournier, A.E.; Lamarche-Vane, N. Hsc70 chaperone activity underlies Trio GEF function in axon growth and guidance induced by netrin-1. J. Cell Biol. 2015, 210, 817-832. [CrossRef] [PubMed]

42. DeGeer, J.; Boudeau, J.; Schmidt, S.; Bedford, F.; Lamarche-Vane, N.; Debant, A. Tyrosine phosphorylation of the Rho guanine nucleotide exchange factor Trio regulates netrin-1/DCC-mediated cortical axon outgrowth. Mol. Cell. Biol. 2013, 33, 739-751. [CrossRef] [PubMed]

43. Lucas, B.; Hardin, J. Mind the (sr)GAP—Roles of Slit-Robo GAPs in neurons, brains and beyond. J. Cell Sci. 2017, 130, 3965-3974. [CrossRef] [PubMed]

44. Yang, L.; Bashaw, G.J. Son of sevenless directly links the Robo receptor to rac activation to control axon repulsion at the midline. Neuron 2006, 52, 595-607. [CrossRef] [PubMed]

45. Conde, C.; Arias, C.; Robin, M.; Li, A.; Saito, M.; Chuang, J.-Z.; Nairn, A.C.; Sung, C.-H.; Cáceres, A. Evidence for the involvement of Lfc and Tctex-1 in axon formation. J. Neurosci. 2010, 30, 6793-6800. [CrossRef] [PubMed]

46. Tudor, E.L.; Perkinton, M.S.; Schmidt, A.; Ackerley, S.; Brownlees, J.; Jacobsen, N.J.O.; Byers, H.L.; Ward, M.; Hall, A.; Leigh, P.N.; et al. ALS2/Alsin regulates Rac-PAK signaling and neurite outgrowth. J. Biol. Chem. 2005, 280, 34735-34740. [CrossRef] [PubMed]

47. Kunita, R.; Otomo, A.; Mizumura, H.; Suzuki-Utsunomiya, K.; Hadano, S.; Ikeda, J.-E. The Rab5 Activator ALS2/alsin Acts as a Novel Rac1 Effector through Rac1-activated Endocytosis. J. Biol. Chem. 2007, 282, 16599-16611. [CrossRef] [PubMed]

48. Vaghi, V.; Pennucci, R.; Talpo, F.; Corbetta, S.; Montinaro, V.; Barone, C.; Croci, L.; Spaiardi, P.; Consalez, G.G.; Biella, G.; et al. Rac1 and Rac3 GTPases control synergistically the development of cortical and hippocampal GABAergic interneurons. Cereb. Cortex 2014, 24, 1247-1258. [CrossRef] [PubMed]

49. Ip, J.P.K.; Shi, L.; Chen, Y.; Itoh, Y.; Fu, W.-Y.; Betz, A.; Yung, W.-H.; Gotoh, Y.; Fu, A.K.Y.; Ip, N.Y. $\alpha 2$-chimaerin controls neuronal migration and functioning of the cerebral cortex through CRMP-2. Nat. Neurosci. 2011, 15, 39-47. [CrossRef] [PubMed]

50. Charrier, C.; Joshi, K.; Coutinho-Budd, J.; Kim, J.-E.; Lambert, N.; de Marchena, J.; Jin, W.-L.; Vanderhaeghen, P.; Ghosh, A.; Sassa, T.; et al. Inhibition of SRGAP2 function by its human-specific paralogs induces neoteny during spine maturation. Cell 2012, 149, 923-935. [CrossRef] [PubMed]

51. Ravindran, E.; Hu, H.; Yuzwa, S.A.; Hernandez-Miranda, L.R.; Kraemer, N.; Ninnemann, O.; Musante, L.; Boltshauser, E.; Schindler, D.; Hübner, A.; et al. Homozygous ARHGEF2 mutation causes intellectual disability and midbrain-hindbrain malformation. PLoS Genet. 2017, 13, e1006746. [CrossRef] [PubMed]

52. Hori, K.; Hoshino, M. Neuronal Migration and AUTS2 Syndrome. Brain Sci. 2017, 7, 54. [CrossRef] [PubMed]

53. Hori, K.; Nagai, T.; Shan, W.; Sakamoto, A.; Taya, S.; Hashimoto, R.; Hayashi, T.; Abe, M.; Yamazaki, M.; Nakao, K.; et al. Cytoskeletal Regulation by AUTS2 in Neuronal Migration and Neuritogenesis. Cell Rep. 2014, 9, 2166-2179. [CrossRef] [PubMed] 
54. Newell-Litwa, K.A.; Badoual, M.; Asmussen, H.; Patel, H.; Whitmore, L.; Horwitz, A.R. ROCK1 and 2 differentially regulate actomyosin organization to drive cell and synaptic polarity. J. Cell Biol. 2015, 210, 225-242. [CrossRef] [PubMed]

55. Tian, D.; Diao, M.; Jiang, Y.; Sun, L.; Zhang, Y.; Chen, Z.; Huang, S.; Ou, G. Anillin Regulates Neuronal Migration and Neurite Growth by Linking RhoG to the Actin Cytoskeleton. Curr. Biol. 2015, 25, 1135-1145. [CrossRef] [PubMed]

56. Woolfrey, K.M.; Srivastava, D.P. Control of Dendritic Spine Morphological and Functional Plasticity by Small GTPases. Neural Plast. 2016, 2016, 3025948. [CrossRef] [PubMed]

57. Newey, S.E.; Velamoor, V.; Govek, E.-E.; Van Aelst, L. Rho GTPases, dendritic structure, and mental retardation. J. Neurobiol. 2005, 64, 58-74. [CrossRef] [PubMed]

58. Li, J.; Zhang, W.; Yang, H.; Howrigan, D.P.; Wilkinson, B.; Souaiaia, T.; Evgrafov, O.V.; Genovese, G.; Clementel, V.A.; Tudor, J.C.; et al. Spatiotemporal profile of postsynaptic interactomes integrates components of complex brain disorders. Nat. Neurosci. 2017, 20, 1150-1161. [CrossRef] [PubMed]

59. Soderling, S.H.; Guire, E.S.; Kaech, S.; White, J.; Zhang, F.; Schutz, K.; Langeberg, L.K.; Banker, G.; Raber, J.; Scott, J.D. A WAVE-1 and WRP signaling complex regulates spine density, synaptic plasticity, and memory. J. Neurosci. 2007, 27, 355-365. [CrossRef] [PubMed]

60. Sarowar, T.; Grabrucker, S.; Föhr, K.; Mangus, K.; Eckert, M.; Bockmann, J.; Boeckers, T.M.; Grabrucker, A.M. Enlarged dendritic spines and pronounced neophobia in mice lacking the PSD protein RICH2. Mol. Brain 2016, 9, 1-24. [CrossRef] [PubMed]

61. Valdez, C.M.; Murphy, G.G.; Beg, A.A. The Rac-GAP alpha2-chimaerin regulates hippocampal dendrite and spine morphogenesis. Mol. Cell. Neurosci. 2016, 75, 14-26. [CrossRef] [PubMed]

62. Long, H.; Zhu, X.; Yang, P.; Gao, Q.; Chen, Y.; Ma, L. Myo9b and RICS modulate dendritic morphology of cortical neurons. Cereb. Cortex 2013, 23, 71-79. [CrossRef] [PubMed]

63. Arber, S.; Barbayannis, F.A.; Hanser, H.; Schneider, C.; Stanyon, C.A.; Bernard, O.; Caroni, P. Regulation of actin dynamics through phosphorylation of cofilin by LIM-kinase. Nature 1998, 393, 805-809. [CrossRef] [PubMed]

64. Rosário, M.; Schuster, S.; Jüttner, R.; Parthasarathy, S.; Tarabykin, V.; Birchmeier, W. Neocortical dendritic complexity is controlled during development by NOMA-GAP-dependent inhibition of Cdc42 and activation of cofilin. Genes Dev. 2012, 26, 1743-1757. [CrossRef] [PubMed]

65. Schuster, S.; Rivalan, M.; Strauss, U.; Stoenica, L.; Trimbuch, T.; Rademacher, N.; Parthasarathy, S.; Lajkó, D.; Rosenmund, C.; Shoichet, S.A.; et al. NOMA-GAP/ARHGAP33 regulates synapse development and autistic-like behavior in the mouse. Mol. Psychiatry 2015, 20, 1120-1131. [CrossRef] [PubMed]

66. Nakano-Kobayashi, A.; Tai, Y.; Nadif Kasri, N.; Van Aelst, L. The X-linked mental retardation protein OPHN1 interacts with Homer1b/c to control spine endocytic zone positioning and expression of synaptic potentiation. J. Neurosci. 2014, 34, 8665-8671. [CrossRef] [PubMed]

67. Cahill, M.E.; Xie, Z.; Day, M.; Photowala, H.; Barbolina, M.V.; Miller, C.A.; Weiss, C.; Radulovic, J.; Sweatt, J.D.; Disterhoft, J.F.; et al. Kalirin regulates cortical spine morphogenesis and disease-related behavioral phenotypes. Proc. Natl. Acad. Sci. USA 2009, 106, 13058-13063. [CrossRef] [PubMed]

68. Xie, Z.; Cahill, M.E.; Penzes, P. Kalirin loss results in cortical morphological alterations. Mol. Cell. Neurosci. 2010, 43, 81-89. [CrossRef] [PubMed]

69. Jaudon, F.; Raynaud, F.; Wehrlé, R.; Bellanger, J.-M.; Doulazmi, M.; Vodjdani, G.; Gasman, S.; Fagni, L.; Dusart, I.; Debant, A.; et al. The RhoGEF DOCK10 is essential for dendritic spine morphogenesis. Mol. Biol. Cell 2015, 26, 2112-2127. [CrossRef] [PubMed]

70. Hamilton, A.M.; Lambert, J.T.; Parajuli, L.K.; Vivas, O.; Park, D.K.; Stein, I.S.; Jahncke, J.N.; Greenberg, M.E.; Margolis, S.S.; Zito, K. A dual role for the RhoGEF Ephexin5 in regulation of dendritic spine outgrowth. Mol. Cell. Neurosci. 2017, 80, 66-74. [CrossRef] [PubMed]

71. Lee, S.; Rudd, S.; Gratten, J.; Visscher, P.M.; Prins, J.B.; Dawson, P.A. Gene networks associated with non-syndromic intellectual disability. J. Neurogenet. 2018, 32, 6-14. [CrossRef] [PubMed]

72. Gaiarsa, J.-L.; Ben-Ari, Y. Long-Term Plasticity at Inhibitory Synapses: A Phenomenon That Has Been Overlooked. In The Dynamic Synapse: Molecular Methods in Ionotropic Receptor Biology; CRC Press: Boca Raton, FL, USA, 2006; ISBN 0849318912.

73. Van Bokhoven, H. Genetic and Epigenetic Networks in Intellectual Disabilities. Annu. Rev. Genet. 2011, 45, 81-104. [CrossRef] [PubMed] 
74. Srivastava, A.K.; Schwartz, C.E. Intellectual disability and autism spectrum disorders: Causal genes and molecular mechanisms. Neurosci. Biobehav. Rev. 2014, 161-174. [CrossRef] [PubMed]

75. McKenzie, K.; Milton, M.; Smith, G.; Ouellette-Kuntz, H. Systematic Review of the Prevalence and Incidence of Intellectual Disabilities: Current Trends and Issues. Curr. Dev. Disord. Rep. 2016, 3, 104-115. [CrossRef]

76. Lelieveld, S.H.; Reijnders, M.R.F.; Pfundt, R.; Yntema, H.G.; Kamsteeg, E.J.; De Vries, P.; De Vries, B.B.A.; Willemsen, M.H.; Kleefstra, T.; Löhner, K.; et al. Meta-analysis of 2104 trios provides support for 10 new genes for intellectual disability. Nat. Neurosci. 2016. [CrossRef] [PubMed]

77. Lelieveld, S.H.; Wiel, L.; Venselaar, H.; Pfundt, R.; Vriend, G.; Veltman, J.A.; Brunner, H.G.; Vissers, L.E.L.M.; Gilissen, C. Spatial Clustering of de Novo Missense Mutations Identifies Candidate Neurodevelopmental Disorder-Associated Genes. Am. J. Hum. Genet. 2017, 101, 478-484. [CrossRef] [PubMed]

78. Reijnders, M.R.F.; Ansor, N.M.; Kousi, M.; Yue, W.W.; Tan, P.L.; Clarkson, K.; Clayton-Smith, J.; Corning, K.; Jones, J.R.; et al. RAC1 Missense Mutations in Developmental Disorders with Diverse Phenotypes. Am. J. Hum. Genet. 2017, 101, 466-477. [CrossRef] [PubMed]

79. Murias, K.; Moir, A.; Myers, K.A.; Liu, I.; Wei, X.-C. Systematic review of MRI findings in children with developmental delay or cognitive impairment. Brain Dev. 2017, 39, 644-655. [CrossRef] [PubMed]

80. Topcu, M.; Yalnizoğlu, D. Developmental abnormalities and mental retardation: Diagnostic strategy. Handb. Clin. Neurol. 2013, 111, 211-217. [CrossRef] [PubMed]

81. Schaefer, G.B.; Bodensteiner, J.B. Radiological findings in developmental delay. Semin. Pediatr. Neurol. 1998, 5, 33-38. [CrossRef]

82. Scorza, C.A.; Cavalheiro, E.A. Animal models of intellectual disability: Towards a translational approach. Clinics 2011, 66, 55-63. [CrossRef] [PubMed]

83. Mottron, L.; Belleville, S.; Rouleau, G.A.; Collignon, O. Linking neocortical, cognitive, and genetic variability in autism with alterations of brain plasticity: The Trigger-Threshold-Target model. Neurosci. Biobehav. Rev. 2014, 47, 735-752. [CrossRef] [PubMed]

84. Ba, W.; van der Raadt, J.; Nadif Kasri, N. Rho GTPase signaling at the synapse: Implications for intellectual disability. Exp. Cell Res. 2013, 319, 2368-2374. [CrossRef] [PubMed]

85. Penzes, P.; Buonanno, A.; Passafaro, M.; Sala, C.; Sweet, R.A. Developmental vulnerability of synapses and circuits associated with neuropsychiatric disorders. J. Neurochem. 2013, 126, 165-182. [CrossRef] [PubMed]

86. Murakoshi, H.; Wang, H.; Yasuda, R. Local, persistent activation of Rho GTPases during plasticity of single dendritic spines. Nature 2011, 472, 100-104. [CrossRef] [PubMed]

87. Tejada-Simon, M.V. Modulation of actin dynamics by Rac1 to target cognitive function. J. Neurochem. 2015, 133, 767-779. [CrossRef] [PubMed]

88. De Filippis, B.; Valenti, D.; Chiodi, V.; Ferrante, A.; de Bari, L.; Fiorentini, C.; Domenici, M.R.; Ricceri, L.; Vacca, R.A.; Fabbri, A.; et al. Modulation of Rho GTPases rescues brain mitochondrial dysfunction, cognitive deficits and aberrant synaptic plasticity in female mice modeling Rett syndrome. Eur. Neuropsychopharmacol. 2015, 25, 889-901. [CrossRef] [PubMed]

89. Fauchereau, F.; Herbrand, U.; Chafey, P.; Eberth, A.; Koulakoff, A.; Vinet, M.-C.; Ahmadian, M.R.; Chelly, J.; Billuart, P. The RhoGAP activity of OPHN1, a new F-actin-binding protein, is negatively controlled by its amino-terminal domain. Mol. Cell. Neurosci. 2003, 23, 574-586. [CrossRef]

90. Billuart, P.; Bienvenu, T.; Ronce, N.; des Portes, V.; Vinet, M.C.; Zemni, R.; Roest Crollius, H.; Carrie, A.; Fauchereau, F.; Cherry, M.; et al. Oligophrenin-1 encodes a rhoGAP protein involved in X-linked mental retard. Nature 1998, 392, 923-926. [CrossRef] [PubMed]

91. Tentler, D.; Gustavsson, P.; Leisti, J.; Schueler, M.; Chelly, J.; Timonen, E.; Annerén, G.; Willard, H.F.; Dahl, N. Deletion including the oligophrenin-1 gene associated with enlarged cerebral ventricles, cerebellar hypoplasia, seizures and ataxia. Eur. J. Hum. Genet. 1999, 7, 541-548. [CrossRef] [PubMed]

92. Zanni, G.; Saillour, Y.; Nagara, M.; Billuart, P.; Castelnau, L.; Moraine, C.; Faivre, L.; Bertini, E.; Durr, A.; Guichet, A.; et al. Oligophrenin 1 mutations frequently cause X-linked mental retardation with cerebellar hypoplasia. Neurology 2005, 65, 1364-1369. [CrossRef] [PubMed] 
93. Al-Owain, M.; Kaya, N.; Al-Zaidan, H.; Al-Hashmi, N.; Al-Bakheet, A.; Al-Muhaizea, M.; Chedrawi, A.; Basran, R.K.; Milunsky, A. Novel intragenic deletion in OPHN1 in a family causing XLMR with cerebellar hypoplasia and distinctive facial appearance. Clin. Genet. 2011, 79, 363-370. [CrossRef] [PubMed]

94. Khelfaoui, M.; Denis, C.; van Galen, E.; de Bock, F.; Schmitt, A.; Houbron, C.; Morice, E.; Giros, B.; Ramakers, G.; Fagni, L.; et al. Loss of X-Linked Mental Retardation Gene Oligophrenin1 in Mice Impairs Spatial Memory and Leads to Ventricular Enlargement and Dendritic Spine Immaturity. J. Neurosci. 2007, 27, 9439-9450. [CrossRef] [PubMed]

95. Valnegri, P.; Montrasio, C.; Brambilla, D.; Ko, J.; Passafaro, M.; Sala, C. The X-linked intellectual disability protein IL1RAPL1 regulates excitatory synapse formation by binding PTPdelta and RhoGAP2. Hum. Mol. Genet. 2011, 20, 4797-4809. [CrossRef] [PubMed]

96. Nadif Kasri, N.; Nakano-Kobayashi, A.; Malinow, R.; Li, B.; Van Aelst, L. The Rho-linked mental retardation protein oligophrenin-1 controls synapse maturation and plasticity by stabilizing AMPA receptors. Genes Dev. 2009, 23, 1289-1302. [CrossRef] [PubMed]

97. Nakano-Kobayashi, A.; Kasri, N.N.; Newey, S.E.; Van Aelst, L. The Rho-Linked Mental Retardation Protein OPHN1 Controls Synaptic Vesicle Endocytosis via Endophilin A1. Curr. Biol. 2009, 19, 1133-1139. [CrossRef] [PubMed]

98. Khelfaoui, M.; Pavlowsky, A.; Powell, A.D.; Valnegri, P.; Cheong, K.W.; Blandin, Y.; Passafaro, M.; Jefferys, J.G.; Chelly, J.; Billuart, P. Inhibition of RhoA pathway rescues the endocytosis defects in Oligophrenin1 mouse model of mental retardation. Hum. Mol. Genet. 2009, 18, 2575-2583. [CrossRef] [PubMed]

99. Govek, E.E.; Newey, S.E.; Akerman, C.J.; Cross, J.R.; Van der Veken, L.; Van Aelst, L. The X-linked mental retardation protein oligophrenin-1 is required for dendritic spine morphogenesis. Nat. Neurosci. 2004, 7, 364-372. [CrossRef] [PubMed]

100. Barresi, S.; Tomaselli, S.; Athanasiadis, A.; Galeano, F.; Locatelli, F.; Bertini, E.; Zanni, G.; Gallo, A. Oligophrenin-1 (OPHN1), a Gene Involved in X-Linked Intellectual Disability, Undergoes RNA Editing and Alternative Splicing during Human Brain Development. PLoS ONE 2014, 9, e91351. [CrossRef] [PubMed]

101. Powell, A.D.; Gill, K.K.; Saintot, P.P.; Jiruska, P.; Chelly, J.; Billuart, P.; Jefferys, J.G.R. Rapid reversal of impaired inhibitory and excitatory transmission but not spine dysgenesis in a mouse model of mental retardation. J. Physiol. 2012, 590, 763-776. [CrossRef] [PubMed]

102. Malosio, M.L.; Gilardelli, D.; Paris, S.; Albertinazzi, C.; de Curtis, I. Differential expression of distinct members of Rho family GTP-binding proteins during neuronal development: Identification of Rac1B, a new neural-specific member of the family. J. Neurosci. 1997, 17, 6717-6728. [CrossRef] [PubMed]

103. Bolis, A.; Corbetta, S.; Cioce, A.; de Curtis, I. Differential distribution of Rac1 and Rac3 GTPases in the developing mouse brain: Implications for a role of Rac3 in Purkinje cell differentiation. Eur. J. Neurosci. 2003, 18, 2417-2424. [CrossRef] [PubMed]

104. Corbetta, S.; Gualdoni, S.; Albertinazzi, C.; Paris, S.; Croci, L.; Consalez, G.G.; de Curtis, I. Generation and Characterization of Rac3 Knockout Mice. Mol. Cell. Biol. 2005, 25, 5763-5776. [CrossRef] [PubMed]

105. Haditsch, U.; Leone, D.P.; Farinelli, M.; Chrostek-Grashoff, A.; Brakebusch, C.; Mansuy, I.M.; McConnell, S.K.; Palmer, T.D. A central role for the small GTPase Rac1 in hippocampal plasticity and spatial learning and memory. Mol. Cell. Neurosci. 2009, 41, 409-419. [CrossRef] [PubMed]

106. Ramakers, G.J.A.; Wolfer, D.; Rosenberger, G.; Kuchenbecker, K.; Kreienkamp, H.J.; Prange-kiel, J.; Rune, G.; Richter, K.; Langnaese, K.; Masneuf, S.; et al. Dysregulation of Rho GTPases in the $\alpha$ Pix/Arhgef6 mouse model of X-linked intellectual disability is paralleled by impaired structural and synaptic plasticity and cognitive deficits. Hum. Mol. Genet. 2012, 21, 268-286. [CrossRef] [PubMed]

107. Peng, Y.-J.; He, W.-Q.; Tang, J.; Tao, T.; Chen, C.; Gao, Y.-Q.; Zhang, W.-C.; He, X.-Y.; Dai, Y.-Y.; Zhu, N.-C.; et al. Trio Is a Key Guanine Nucleotide Exchange Factor Coordinating Regulation of the Migration and Morphogenesis of Granule Cells in the Developing Cerebellum. J. Biol. Chem. 2010, 285, 24834-24844. [CrossRef] [PubMed]

108. Chen, L.; Liao, G.; Waclaw, R.R.; Burns, K.A.; Linquist, D.; Campbell, K.; Zheng, Y.; Kuan, C.-Y. Rac1 Controls the Formation of Midline Commissures and the Competency of Tangential Migration in Ventral Telencephalic Neurons. J. Neurosci. 2007, 27, 3884-3893. [CrossRef] [PubMed] 
109. Meng, Y.; Zhang, Y.; Tregoubov, V.; Janus, C.; Cruz, L.; Jackson, M.; Lu, W.Y.; MacDonald, J.F.; Wang, J.Y.; Falls, D.L.; et al. Abnormal spine morphology and enhanced LTP in LIMK-1 knockout mice. Neuron 2002, 35, 121-133. [CrossRef]

110. Bongmba, O.Y.N.; Martinez, L.A.; Elhardt, M.E.; Butler, K.; Tejada-Simon, M.V. Modulation of dendritic spines and synaptic function by Rac1: A possible link to Fragile $X$ syndrome pathology. Brain Res. 2011, 1399, 79-95. [CrossRef] [PubMed]

111. Pennucci, R.; Talpo, F.; Astro, V.; Montinaro, V.; Morè, L.; Cursi, M.; Castoldi, V.; Chiaretti, S.; Bianchi, V.; Marenna, S.; et al. Loss of Either Rac1 or Rac3 GTPase Differentially Affects the Behavior of Mutant Mice and the Development of Functional GABAergic Networks. Cereb. Cortex 2016, 26, 873-890. [CrossRef] [PubMed]

112. Hayashi, M.L.; Choi, S.-Y.; Rao, B.S.S.; Jung, H.-Y.; Lee, H.-K.; Zhang, D.; Chattarji, S.; Kirkwood, A.; Tonegawa, S. Altered Cortical Synaptic Morphology and Impaired Memory Consolidation in ForebrainSpecific Dominant-Negative PAK Transgenic Mice. Neuron 2004, 42, 773-787. [CrossRef] [PubMed]

113. Ba, W.; Yan, Y.; Reijnders, M.R.F.; Schuurs-Hoeijmakers, J.H.M.; Feenstra, I.; Bongers, E.M.H.F.; Bosch, D.G.M.; De Leeuw, N.; Pfundt, R.; Gilissen, C.; et al. TRIO loss of function is associated with mild intellectual disability and affects dendritic branching and synapse function. Hum. Mol. Genet. 2016, 25, 892-902. [CrossRef] [PubMed]

114. Jedlicka, P.; Papadopoulos, T.; Deller, T.; Betz, H.; Schwarzacher, S.W. Increased network excitability and impaired induction of long-term potentiation in the dentate gyrus of collybistin-deficient mice in vivo. Mol. Cell. Neurosci. 2009, 41, 94-100. [CrossRef] [PubMed]

115. Papadopoulos, T.; Korte, M.; Eulenburg, V.; Kubota, H.; Retiounskaia, M.; Harvey, R.J.; Harvey, K.; O'Sullivan, G.A.; Laube, B.; Hülsmann, S.; et al. Impaired GABAergic transmission and altered hippocampal synaptic plasticity in collybistin-deficient mice. EMBO J. 2007, 26, 3888-3899. [CrossRef] [PubMed]

116. Threadgill, R.; Bobb, K.; Ghosh, A. Regulation of Dendritic Growth and Remodeling by Rho, Rac, and Cdc42. Neuron 1997, 19, 625-634. [CrossRef]

117. Nakayama, A.Y.; Harms, M.B.; Luo, L. Small GTPases Rac and Rho in the maintenance of dendritic spines and branches in hippocampal pyramidal neurons. J. Neurosci. 2000, 20, 5329-5338. [CrossRef] [PubMed]

118. Sugihara, K.; Nakatsuji, N.; Nakamura, K.; Nakao, K.; Hashimoto, R.; Otani, H.; Sakagami, H.; Kondo, H.; Nozawa, S.; Aiba, A.; et al. Rac1 is required for the formation of three germ layers during gastrulation. Oncogene 1998, 17, 3427-3433. [CrossRef] [PubMed]

119. Vidaki, M.; Tivodar, S.; Doulgeraki, K.; Tybulewicz, V.; Kessaris, N.; Pachnis, V.; Karagogeos, D. Rac1-dependent cell cycle exit of MGE precursors and gabaergic interneuron migration to the cortex. Cereb. Cortex 2012, 22, 680-692. [CrossRef] [PubMed]

120. Batista-Brito, R.; Fishell, G. Chapter 3-The Developmental Integration of Cortical Interneurons into a Functional Network. In Current Topics in Developmental Biology; Elsevier: New York, NY, USA, 2009; Volume 87, pp. 81-118.

121. Gelman, D.M.; Marín, O. Generation of interneuron diversity in the mouse cerebral cortex. Eur. J. Neurosci. 2010, 31, 2136-2141. [CrossRef] [PubMed]

122. Brooks-Kayal, A. Molecular mechanisms of cognitive and behavioral comorbidities of epilepsy in children. Epilepsia 2011, 52, 13-20. [CrossRef] [PubMed]

123. Hernández-Miranda, L.R.; Parnavelas, J.G.; Chiara, F. Molecules and Mechanisms Involved in the Generation and Migration of Cortical Interneurons. ASN Neuro 2010, 2, AN20090053. [CrossRef] [PubMed]

124. Zhao, Z.-S.; Manser, E. PAK family kinases: Physiological roles and regulation. Cell. Logist. 2012, 2, 59-68. [CrossRef] [PubMed]

125. Allen, K.M.; Gleeson, J.G.; Bagrodia, S.; Partington, M.W.; MacMillan, J.C.; Cerione, R.A.; Mulley, J.C.; Walsh, C.A. PAK3 mutation in nonsyndromic X-linked mental retardation. Nat. Genet. 1998, 20, 25-30. [CrossRef] [PubMed]

126. Bienvenu, T.; des Portes, V.; McDonell, N.; Carrié, A.; Zemni, R.; Couvert, P.; Ropers, H.H.; Moraine, C.; van Bokhoven, H.; Fryns, J.P.; et al. Missense mutation in PAK3, R67C, causes X-linked nonspecific mental retardation. Am. J. Med. Genet. 2000, 93, 294-298. [CrossRef]

127. Donnelly, A.J.; Partington, M.W.; Ryan, A.K.; Mulley, J.C. Regional localisation of two non-specific X-linked mental retardation genes (MRX30 and MRX31). Am. J. Med. Genet. 1996, 64, 113-120. [CrossRef] 
128. Des Portes, V.; Soufir, N.; Carrié, A.; Billuart, P.; Bienvenu, T.; Vinet, M.C.; Beldjord, C.; Ponsot, G.; Kahn, A.; Boué, J.; et al. Gene for nonspecific X-linked mental retardation (MRX 47) is located in Xq22.3-q24. Am. J. Med. Genet. 1997, 72, 324-328. [CrossRef]

129. Gedeon, A.K.; Nelson, J.; Gécz, J.; Mulley, J.C. X-linked mild non-syndromic mental retardation with neuropsychiatric problems and the missense mutation A365E in PAK3. Am. J. Med. Genet. A 2003, 120A, 509-517. [CrossRef] [PubMed]

130. Peippo, M.; Koivisto, A.M.; Särkämö, T.; Sipponen, M.; von Koskull, H.; Ylisaukko-oja, T.; Rehnström, K.; Froyen, G.; Ignatius, J.; Järvelä, I. PAK3 related mental disability: Further characterization of the phenotype. Am. J. Med. Genet. A 2007, 143A, 2406-2416. [CrossRef] [PubMed]

131. Rejeb, I.; Saillour, Y.; Castelnau, L.; Julien, C.; Bienvenu, T.; Taga, P.; Chaabouni, H.; Chelly, J.; Ben Jemaa, L.; Bahi-Buisson, N. A novel splice mutation in PAK3 gene underlying mental retardation with neuropsychiatric features. Eur. J. Hum. Genet. 2008, 16, 1358-1363. [CrossRef] [PubMed]

132. Dubos, A.; Combeau, G.; Bernardinelli, Y.; Barnier, J.-V.; Hartley, O.; Gaertner, H.; Boda, B.; Muller, D. Alteration of Synaptic Network Dynamics by the Intellectual Disability Protein PAK3. J. Neurosci. 2012, 32, 519-527. [CrossRef] [PubMed]

133. Meng, J. Abnormal Long-Lasting Synaptic Plasticity and Cognition in Mice Lacking the Mental Retardation Gene Pak3. J. Neurosci. 2005, 25, 6641-6650. [CrossRef] [PubMed]

134. Manser, E.; Chong, C.; Zhao, Z.S.; Leung, T.; Michael, G.; Hall, C.; Lim, L. Molecular cloning of a new member of the p21-Cdc42/Rac-activated kinase (PAK) family. J. Biol. Chem. 1995, 270, 25070-25078. [CrossRef] [PubMed]

135. Boda, B.; Alberi, S.; Nikonenko, I.; Node-Langlois, R.; Jourdain, P.; Moosmayer, M.; Parisi-Jourdain, L.; Muller, D. The Mental Retardation Protein PAK3 Contributes to Synapse Formation and Plasticity in Hippocampus. J. Neurosci. 2004, 24, 10816-10825. [CrossRef] [PubMed]

136. Nodé-Langlois, R.; Muller, D.; Boda, B. Sequential implication of the mental retardation proteins ARHGEF6 and PAK3 in spine morphogenesis. J. Cell Sci. 2006, 119, 4986-4993. [CrossRef] [PubMed]

137. Baird, D.; Feng, Q.; Cerione, R.A. The Cool-2/ $\alpha$-Pix Protein Mediates a Cdc42-Rac Signaling Cascade. Curr. Biol. 2005, 15, 1-10. [CrossRef] [PubMed]

138. Kutsche, K.; Yntema, H.; Brandt, A.; Jantke, I.; Gerd Nothwang, H.; Orth, U.; Boavida, M.G.; David, D.; Chelly, J.; Fryns, J.-P.; et al. Mutations in ARHGEF6, encoding a guanine nucleotide exchange factor for Rho GTPases, in patients with X-linked mental retardation. Nat. Genet. 2000, 26, 247-250. [CrossRef] [PubMed]

139. Reid, T.; Bathoorn, A.; Ahmadian, M.R.; Collard, J.G. Identification and characterization of hPEM-2, a guanine nucleotide exchange factor specific for Cdc42. J. Biol. Chem. 1999, 274, 33587-33593. [CrossRef] [PubMed]

140. Kalscheuer, V.M.; Musante, L.; Fang, C.; Hoffmann, K.; Fuchs, C.; Carta, E.; Deas, E.; Venkateswarlu, K.; Menzel, C.; Ullmann, R.; et al. A balanced chromosomal translocation disrupting ARHGEF9 is associated with epilepsy, anxiety, aggression, and mental retardation. Hum. Mutat. 2009, 30, 61-68. [CrossRef] [PubMed]

141. Lemke, J.R.; Riesch, E.; Scheurenbrand, T.; Schubach, M.; Wilhelm, C.; Steiner, I.; Hansen, J.; Courage, C.; Gallati, S.; Bürki, S.; et al. Targeted next generation sequencing as a diagnostic tool in epileptic disorders. Epilepsia 2012, 53, 1387-1398. [CrossRef] [PubMed]

142. Long, P.; May, M.M.; James, V.M.; Grannò, S.; Johnson, J.P.; Tarpey, P.; Stevenson, R.E.; Harvey, K.; Schwartz, C.E.; Harvey, R.J. Missense Mutation R338W in ARHGEF9 in a Family with X-linked Intellectual Disability with Variable Macrocephaly and Macro-Orchidism. Front. Mol. Neurosci. 2015, 8, 83. [CrossRef] [PubMed]

143. Klein, K.M.; Pendziwiat, M.; Eilam, A.; Gilad, R.; Blatt, I.; Rosenow, F.; Kanaan, M.; Helbig, I.; Afawi, Z.; Israeli-Palestinian Epilepsy Family Consortium. The phenotypic spectrum of ARHGEF9 includes intellectual disability, focal epilepsy and febrile seizures. J. Neurol. 2017, 264, 1421-1425. [CrossRef] [PubMed]

144. Machado, C.O.F.; Griesi-Oliveira, K.; Rosenberg, C.; Kok, F.; Martins, S.; Passos-Bueno, M.R.; Sertie, A.L. Collybistin binds and inhibits mTORC1 signaling: A potential novel mechanism contributing to intellectual disability and autism. Eur. J. Hum. Genet. 2016, 24, 59-65. [CrossRef] [PubMed]

145. De Groot, C.; Floriou-Servou, A.; Tsai, Y.-C.; Früh, S.; Kohler, M.; Parkin, G.; Schwerdel, C.; Bosshard, G.; Kaila, K.; Fritschy, J.-M.; et al. RhoGEF9 splice isoforms influence neuronal maturation and synapse formation downstream of $\alpha 2$ GABAA receptors. PLoS Genet. 2017, 13, e1007073. [CrossRef] [PubMed] 
146. Zheng, Y.; Fischer, D.J.; Santos, M.F.; Tigyi, G.; Pasteris, N.G.; Gorski, J.L.; Xu, Y. The faciogenital dysplasia gene product FGD1 functions as a Cdc42Hs-specific guanine-nucleotide exchange factor. J. Biol. Chem. 1996, 271, 33169-33172. [CrossRef] [PubMed]

147. Martínez-Castellano, F. Non-specific X-linked mental retardation (in Spanish). Rev. Neurol. 2006, 42, S77-S83. [PubMed]

148. Pasteris, N.G.; Cadle, A.; Logie, L.J.; Porteous, M.E.; Schwartz, C.E.; Stevenson, R.E.; Glover, T.W.; Wilroy, R.S.; Gorski, J.L. Isolation and characterization of the faciogenital dysplasia (Aarskog-Scott syndrome) gene: A putative Rho/Rac guanine nucleotide exchange factor. Cell 1994, 79, 669-678. [CrossRef]

149. Lebel, R.R.; May, M.; Pouls, S.; Lubs, H.A.; Stevenson, R.E.; Schwartz, C.E. Non-syndromic X-linked mental retardation associated with a missense mutation (P312L) in the FGD1 gene. Clin. Genet. 2002, 61, 139-145. [CrossRef] [PubMed]

150. Olson, M.F.; Pasteris, N.G.; Gorski, J.L.; Hall, A. Faciogenital dysplasia protein (FGD1) and Vav, two related proteins required for normal embryonic development, are upstream regulators of Rho GTPases. Curr. Biol. 1996, 6, 1628-1633. [CrossRef]

151. Estrada, L.; Caron, E.; Gorski, J.L. Fgd1, the Cdc42 guanine nucleotide exchange factor responsible for faciogenital dysplasia, is localized to the subcortical actin cytoskeleton and Golgi membrane. Hum. Mol. Genet. 2001, 10, 485-495. [CrossRef] [PubMed]

152. Schmidt, S.; Debant, A. Function and regulation of the Rho guanine nucleotide exchange factor Trio. Small GTPases 2014, 5, e29769. [CrossRef] [PubMed]

153. Jaiswal, M.; Dvorsky, R.; Ahmadian, M.R. Deciphering the Molecular and Functional Basis of Dbl Family Proteins. J. Biol. Chem. 2013, 288, 4486-4500. [CrossRef] [PubMed]

154. Blangy, A.; Vignal, E.; Schmidt, S.; Debant, A.; Gauthier-Rouvière, C.; Fort, P. TrioGEF1 controls Racand Cdc42-dependent cell structures through the direct activation of rhoG. J. Cell Sci. 2000, 113, 729-739. [PubMed]

155. Ma, X.-M.; Huang, J.-P.; Eipper, B.A.; Mains, R.E. Expression of Trio, a member of the Dbl family of Rho GEFs in the developing rat brain. J. Comp. Neurol. 2005, 482, 333-348. [CrossRef] [PubMed]

156. Portales-Casamar, E.; Briançon-Marjollet, A.; Fromont, S.; Triboulet, R.; Debant, A. Identification of novel neuronal isoforms of the Rho-GEF Trio. Biol. Cell 2006, 98, 183-193. [CrossRef] [PubMed]

157. Pengelly, R.J.; Greville-Heygate, S.; Schmidt, S.; Seaby, E.G.; Jabalameli, M.R.; Mehta, S.G.; Parker, M.J.; Goudie, D.; Fagotto-Kaufmann, C.; Mercer, C.; et al. Mutations specific to the Rac-GEF domain of TRIO cause intellectual disability and microcephaly. J. Med. Genet. 2016, 53, 735-742. [CrossRef] [PubMed]

158. Zong, W.; Liu, S.; Wang, X.; Zhang, J.; Zhang, T.; Liu, Z.; Wang, D.; Zhang, A.; Zhu, M.; Gao, J. Trio gene is required for mouse learning ability. Brain Res. 2015, 1608, 82-90. [CrossRef] [PubMed]

159. O'Brien, S.P.; Seipel, K.; Medley, Q.G.; Bronson, R.; Segal, R.; Streuli, M. Skeletal muscle deformity and neuronal disorder in Trio exchange factor-deficient mouse embryos. Proc. Natl. Acad. Sci. USA 2000, 97, 12074-12078. [CrossRef] [PubMed]

160. Orsini, A.; Bonuccelli, A.; Striano, P.; Azzara, A.; Costagliola, G.; Consolini, R.; Peroni, D.G.; Valetto, A.; Bertini, V. Generalized epilepsy and mild intellectual disability associated with 13q34 deletion: A potential role for SOX1 and ARHGEF7. Seizure 2018, 59, 38-40. [CrossRef] [PubMed]

161. Zeidán-Chuliá, F.; Salmina, A.B.; Noda, M.; Verkhratsky, A. Rho GTPase RAC1 at the Molecular Interface Between Genetic and Environmental Factors of Autism Spectrum Disorders. Neuromol. Med. 2015, 17, 333-334. [CrossRef] [PubMed]

162. Dong, T.; He, J.; Wang, S.; Wang, L.; Cheng, Y.; Zhong, Y. Inability to activate Rac1-dependent forgetting contributes to behavioral inflexibility in mutants of multiple autism-risk genes. Proc. Natl. Acad. Sci. USA 2016, 113, 7644-7649. [CrossRef] [PubMed]

163. Sadybekov, A.; Tian, C.; Arnesano, C.; Katritch, V.; Herring, B.E. An autism spectrum disorder-related de novo mutation hotspot discovered in the GEF1 domain of Trio. Nat. Commun. 2017, 8, 1-12. [CrossRef] [PubMed]

164. Golden, S.A.; Christoffel, D.J.; Hodes, G.E.; Heshmati, M.; Magida, J.; Davis, K.; Cahill, M.E.; Dias, C.; Ribeiro, E.; Ables, J.L.; et al. Epigenetic regulation of synaptic remodeling in stress disorders. Nat. Med. 2013, 19, 337-344. [CrossRef] [PubMed] 
165. Pyronneau, A.; He, Q.; Hwang, J.-Y.; Porch, M.; Contractor, A.; Zukin, R.S. Aberrant Rac1-cofilin signaling mediates defects in dendritic spines, synaptic function, and sensory perception in fragile $\mathrm{X}$ syndrome. Sci. Signal. 2017, 10, eaan0852. [CrossRef] [PubMed]

166. Aguilar, B.J.; Zhu, Y.; Lu, Q. Rho GTPases as therapeutic targets in Alzheimer's disease. Alzheimers Res. Ther. 2017, 9, 97. [CrossRef] [PubMed]

167. Kato, T.; Konishi, Y.; Shimohama, S.; Beach, T.G.; Akatsu, H.; Tooyama, I. Alpha1-chimaerin, a Rac1 GTPase-activating protein, is expressed at reduced mRNA levels in the brain of Alzheimer's disease patients. Neurosci. Lett. 2015, 591, 19-24. [CrossRef] [PubMed]

168. Wang, P.-L.; Niidome, T.; Akaike, A.; Kihara, T.; Sugimoto, H. Rac1 inhibition negatively regulates transcriptional activity of the amyloid precursor protein gene. J. Neurosci. Res. 2009, 87, 2105-2114. [CrossRef] [PubMed]

169. Verhoeven, W.M.A.; Egger, J.I.M.; Hoogeboom, A.J.M. X-linked Aarskog syndrome: Report on a novel FGD1 gene mutation. Executive dysfunction as part of the behavioural phenotype. Genet. Couns. 2012, 23, 157-167. [PubMed]

170. Orrico, A.; Galli, L.; Faivre, L.; Clayton-Smith, J.; Azzarello-Burri, S.M.; Hertz, J.M.; Jacquemont, S.; Taurisano, R.; Arroyo Carrera, I.; Tarantino, E.; et al. Aarskog-Scott syndrome: Clinical update and report of nine novel mutations of the FGD1 gene. Am. J. Med. Genet. Part A 2010, 152A, 313-318. [CrossRef] [PubMed]

171. Mulatinho, M.V.; de Carvalho Serao, C.L.; Scalco, F.; Hardekopf, D.; Pekova, S.; Mrasek, K.; Liehr, T.; Weise, A.; Rao, N.; Llerena, J.C., Jr. Severe intellectual disability, omphalocele, hypospadia and high blood pressure associated to a deletion at 2q22.1q22.3: Case report. Mol. Cytogenet. 2012, 5, 30. [CrossRef] [PubMed]

172. Smigiel, R.; Szafranska, A.; Czyzewska, M.; Rauch, A.; Zweier, C.; Patkowski, D. Severe clinical course of Hirschsprung disease in a Mowat-Wilson syndrome patient. J. Appl. Genet. 2010, 51, 111-113. [CrossRef] [PubMed]

173. Dastot-Le Moal, F.; Wilson, M.; Mowat, D.; Collot, N.; Niel, F.; Goossens, M. ZFHX1B mutations in patients with Mowat-Wilson syndrome. Hum. Mutat. 2007, 28, 313-321. [CrossRef] [PubMed]

174. Maeda, M.; Hasegawa, H.; Hyodo, T.; Ito, S.; Asano, E.; Yuang, H.; Funasaka, K.; Shimokata, K.; Hasegawa, Y.; Hamaguchi, M.; et al. ARHGAP18, a GTPase-activating protein for RhoA, controls cell shape, spreading, and motility. Mol. Biol. Cell 2011, 22, 3840-3852. [CrossRef] [PubMed]

175. Potkin, S.G.; Turner, J.A.; Fallon, J.A.; Lakatos, A.; Keator, D.B.; Guffanti, G.; Macciardi, F. Gene discovery through imaging genetics: Identification of two novel genes associated with schizophrenia. Mol. Psychiatry 2009, 14, 416-428. [CrossRef] [PubMed]

176. Potkin, S.G.; Macciardi, F.; Guffanti, G.; Fallon, J.H.; Wang, Q.; Turner, J.A.; Lakatos, A.; Miles, M.F.; Lander, A.; Vawter, M.P.; et al. Identifying gene regulatory networks in schizophrenia. Neuroimage 2010, 53, 839-847. [CrossRef] [PubMed]

177. Hamdan, F.F.; Gauthier, J.; Spiegelman, D.; Noreau, A.; Yang, Y.; Pellerin, S.; Dobrzeniecka, S.; Côté, M.; Perreau-Linck, E.; Carmant, L.; et al. Synapse to Disease Group Mutations in SYNGAP1 in Autosomal Nonsyndromic Mental Retardation. N. Engl. J. Med. 2009, 360, 599-605. [CrossRef] [PubMed]

178. Chen, Q.; Zhu, Y.-C.; Yu, J.; Miao, S.; Zheng, J.; Xu, L.; Zhou, Y.; Li, D.; Zhang, C.; Tao, J.; et al. CDKL5, a Protein Associated with Rett Syndrome, Regulates Neuronal Morphogenesis via Rac1 Signaling. J. Neurosci. 2010, 30, 12777-12786. [CrossRef] [PubMed]

179. Bamburg, J.R.; Bray, D. Distribution and cellular localization of actin depolymerizing factor. J. Cell Biol. 1987, 105, 2817-2825. [CrossRef] [PubMed]

180. Mori, T.; Okano, I.; Mizuno, K.; Tohyama, M.; Wanaka, A. Comparison of tissue distribution of two novel serine/threonine kinase genes containing the LIM motif (LIMK-1 and LIMK-2) in the developing rat. Brain Res. Mol. Brain Res. 1997, 45, 247-254. [CrossRef]

181. Cuberos, H.; Vallée, B.; Vourc'h, P.; Tastet, J.; Andres, C.R.; Bénédetti, H. Roles of LIM kinases in central nervous system function and dysfunction. FEBS Lett. 2015, 589, 3795-3806. [CrossRef] [PubMed]

182. Bernard, O.; Ganiatsas, S.; Kannourakis, G.; Dringen, R. Kiz-1, a protein with LIM zinc finger and kinase domains, is expressed mainly in neurons. Cell Growth Differ. 1994, 5, 1159-1171. [PubMed]

183. Mizuno, K.; Okano, I.; Ohashi, K.; Nunoue, K.; Kuma, K.; Miyata, T.; Nakamura, T. Identification of a human cDNA encoding a novel protein kinase with two repeats of the LIM/double zinc finger motif. Oncogene 1994, 9, 1605-1612. [PubMed] 
184. Pröschel, C.; Blouin, M.J.; Gutowski, N.J.; Ludwig, R.; Noble, M. Limk1 is predominantly expressed in neural tissues and phosphorylates serine, threonine and tyrosine residues in vitro. Oncogene 1995, 11, 1271-1281. [PubMed]

185. Wang, J.Y.; Wigston, D.J.; Rees, H.D.; Levey, A.I.; Falls, D.L. LIM kinase 1 accumulates in presynaptic terminals during synapse maturation. J. Comp. Neurol. 2000, 416, 319-334. [CrossRef]

186. Gauthier-Fisher, A.; Lin, D.C.; Greeve, M.; Kaplan, D.R.; Rottapel, R.; Miller, F.D. Lfc and Tctex-1 regulate the genesis of neurons from cortical precursor cells. Nat. Neurosci. 2009. [CrossRef] [PubMed]

187. Ryan, X.P.; Alldritt, J.; Svenningsson, P.; Allen, P.B.; Wu, G.-Y.; Nairn, A.C.; Greengard, P. The Rho-Specific GEF Lfc Interacts with Neurabin and Spinophilin to Regulate Dendritic Spine Morphology Neurabin and the structurally related protein, spinophi. Neuron 2005, 47, 85-100. [CrossRef] [PubMed]

188. Ba, W.; Selten, M.M.; van der Raadt, J.; van Veen, H.; Li, L.-L.; Benevento, M.; Oudakker, A.R.; Lasabuda, R.S.E.; Letteboer, S.J.; Roepman, R.; et al. ARHGAP12 Functions as a Developmental Brake on Excitatory Synapse Function. Cell Rep. 2016, 14, 1355-1368. [CrossRef] [PubMed]

189. Martin-Vilchez, S.; Whitmore, L.; Asmussen, H.; Zareno, J.; Horwitz, R.; Newell-Litwa, K. RhoGTPase Regulators Orchestrate Distinct Stages of Synaptic Development. PLoS ONE 2017, 12, e0170464. [CrossRef] [PubMed]

190. Picker, J.D.; Walsh, C.A. New innovations: Therapeutic opportunities for intellectual disabilities. Ann. Neurol. 2013, 74, 382-390. [CrossRef] [PubMed]

191. Guy, J.; Hendrich, B.; Holmes, M.; Martin, J.E.; Bird, A. A mouse Mecp2-null mutation causes neurological symptoms that mimic Rett syndrome. Nat. Genet. 2001, 27, 322-326. [CrossRef] [PubMed]

192. Garg, S.K.; Lioy, D.T.; Cheval, H.; McGann, J.C.; Bissonnette, J.M.; Murtha, M.J.; Foust, K.D.; Kaspar, B.K.; Bird, A.; Mandel, G. Systemic delivery of MeCP2 rescues behavioral and cellular deficits in female mouse models of Rett syndrome. J. Neurosci. 2013, 33, 13612-13620. [CrossRef] [PubMed]

193. Reeves, R.H.; Irving, N.G.; Moran, T.H.; Wohn, A.; Kitt, C.; Sisodia, S.S.; Schmidt, C.; Bronson, R.T.; Davisson, M.T. A mouse model for Down syndrome exhibits learning and behaviour deficits. Nat. Genet. 1995, 11, 177-184. [CrossRef] [PubMed]

194. Dierssen, M. Down syndrome: The brain in trisomic mode. Nat. Rev. Neurosci. 2012, 13, 844-858. [CrossRef] [PubMed]

195. Chakrabarti, L.; Best, T.K.; Cramer, N.P.; Carney, R.S.E.; Isaac, J.T.R.; Galdzicki, Z.; Haydar, T.F. Olig1 and Olig2 triplication causes developmental brain defects in Down syndrome. Nat. Neurosci. 2010, 13, 927-934. [CrossRef] [PubMed]

196. Kleschevnikov, A.M.; Belichenko, P.V.; Villar, A.J.; Epstein, C.J.; Malenka, R.C.; Mobley, W.C. Hippocampal long-term potentiation suppressed by increased inhibition in the Ts65Dn mouse, a genetic model of Down syndrome. J. Neurosci. 2004, 24, 8153-8160. [CrossRef] [PubMed]

197. Costa, A.C.S.; Grybko, M.J. Deficits in hippocampal CA1 LTP induced by TBS but not HFS in the Ts65Dn mouse: A model of Down syndrome. Neurosci. Lett. 2005, 382, 317-322. [CrossRef] [PubMed]

198. Costa, A.C.S.; Scott-McKean, J.J.; Stasko, M.R. Acute injections of the NMDA receptor antagonist memantine rescue performance deficits of the Ts65Dn mouse model of Down syndrome on a fear conditioning test. Neuropsychopharmacology 2008, 33, 1624-1632. [CrossRef] [PubMed]

199. Deidda, G.; Parrini, M.; Naskar, S.; Bozarth, I.F.; Contestabile, A.; Cancedda, L. Reversing excitatory GABAAR signaling restores synaptic plasticity and memory in a mouse model of Down syndrome. Nat. Med. 2015, 21, 318-326. [CrossRef] [PubMed]

200. Borrelli, S.; Musilli, M.; Martino, A.; Diana, G. Long-lasting efficacy of the cognitive enhancer cytotoxic necrotizing factor 1. Neuropharmacology 2013, 64, 74-80. [CrossRef] [PubMed]

201. Musilli, M.; Nicolia, V.; Borrelli, S.; Scarpa, S.; Diana, G. Behavioral effects of Rho GTPase modulation in a model of Alzheimer's disease. Behav. Brain Res. 2013, 237, 223-229. [CrossRef] [PubMed]

202. Huentelman, M.J.; Stephan, D.A.; Talboom, J.; Corneveaux, J.J.; Reiman, D.M.; Gerber, J.D.; Barnes, C.A.; Alexander, G.E.; Reiman, E.M.; Bimonte-Nelson, H.A. Peripheral delivery of a ROCK inhibitor improves learning and working memory. Behav. Neurosci. 2009, 123, 218-223. [CrossRef] [PubMed]

203. Hou, Y.; Zhou, L.; Yang, Q.D.; Du, X.P.; Li, M.; Yuan, M.; Zhou, Z.W. Changes in hippocampal synapses and learning-memory abilities in a streptozotocin-treated rat model and intervention by using fasudil hydrochloride. Neuroscience 2012, 200, 120-129. [CrossRef] [PubMed] 
204. Asano, T.; Suzuki, T.; Tsuchiya, M.; Satoh, S.; Ikegaki, I.; Shibuya, M.; Suzuki, Y.; Hidaka, H. Vasodilator actions of HA1077 in vitro and in vivo putatively mediated by the inhibition of protein kinase. Br. J. Pharmacol. 1989, 98, 1091-1100. [CrossRef] [PubMed]

205. Tatenhorst, L.; Eckermann, K.; Dambeck, V.; Fonseca-Ornelas, L.; Walle, H.; da Fonseca, T.L.; Koch, J.C.; Becker, S.; Tönges, L.; Bähr, M.; et al. Fasudil attenuates aggregation of $\alpha$-synuclein in models of Parkinson's disease. Acta Neuropathol. Commun. 2016, 4, 39. [CrossRef] [PubMed]

206. Suzuki, Y.; Shibuya, M.; Satoh, S.-I.; Sugimoto, Y.; Takakura, K. A postmarketing surveillance study of fasudil treatment after aneurysmal subarachnoid hemorrhage. Surg. Neurol. 2007, 68, 126-131. [CrossRef] [PubMed]

207. Shibuya, M.; Hirai, S.; Seto, M.; Satoh, S.; Ohtomo, E.; Fasudil Ischemic Stroke Study Group. Effects of fasudil in acute ischemic stroke: Results of a prospective placebo-controlled double-blind trial. J. Neurol. Sci. 2005, 238, 31-39. [CrossRef] [PubMed]

208. Mueller, B.K.; Mack, H.; Teusch, N. Rho kinase, a promising drug target for neurological disorders. Nat. Rev. Drug Discov. 2005, 4, 387-398. [CrossRef] [PubMed]

209. Günther, R.; Saal, K.-A.; Suhr, M.; Scheer, D.; Koch, J.C.; Bähr, M.; Lingor, P.; Tönges, L. The rho kinase inhibitor Y-27632 improves motor performance in male SOD1(G93A) mice. Front. Neurosci. 2014, 8, 304. [CrossRef] [PubMed]

210. Inan, S.Y.; Soner, B.C.; Sahin, A.S. Behavioural effects of basal ganglia rho-kinase inhibition in the unilateral 6-hydroxydopamine rat model of Parkinson's disease. Metab. Brain Dis. 2016, 31, 849-857. [CrossRef] [PubMed]

211. Villar-Cheda, B.; Dominguez-Meijide, A.; Joglar, B.; Rodriguez-Perez, A.I.; Guerra, M.J.; Labandeira-Garcia, J.L. Involvement of microglial RhoA/Rho-kinase pathway activation in the dopaminergic neuron death. Role of angiotensin via angiotensin type 1 receptors. Neurobiol. Dis. 2012, 47, 268-279. [CrossRef] [PubMed]

212. Khelfaoui, M.; Gambino, F.; Houbaert, X.; Ragazzon, B.; Müller, C.; Carta, M.; Lanore, F.; Srikumar, B.N.; Gastrein, P.; Lepleux, M.; et al. Lack of the presynaptic RhoGAP protein oligophrenin1 leads to cognitive disabilities through dysregulation of the cAMP/PKA signalling pathway. Philos. Trans. R. Soc. B Biol. Sci. 2014, 369, 20130160. [CrossRef] [PubMed]

213. Meziane, H.; Khelfaoui, M.; Morello, N.; Hiba, B.; Calcagno, E.; Reibel-Foisset, S.; Selloum, M.; Chelly, J.; Humeau, Y.; Riet, F.; et al. Fasudil treatment in adult reverses behavioural changes and brain ventricular enlargement in Oligophrenin-1 mouse model of intellectual disability. Hum. Mol. Genet. 2016, 25, 2314-2323. [CrossRef] [PubMed]

214. Ehninger, D.; Li, W.; Fox, K.; Stryker, M.P.; Silva, A.J. Reversing neurodevelopmental disorders in adults. Neuron 2008, 60, 950-960. [CrossRef] [PubMed]

215. Castrén, E.; Rantamäki, T. The role of BDNF and its receptors in depression and antidepressant drug action: Reactivation of developmental plasticity. Dev. Neurobiol. 2010, 70, 289-297. [CrossRef] [PubMed]

216. Allegra, M.; Spalletti, C.; Vignoli, B.; Azzimondi, S.; Busti, I.; Billuart, P.; Canossa, M.; Caleo, M. Pharmacological rescue of adult hippocampal neurogenesis in a mouse model of X-linked intellectual disability. Neurobiol. Dis. 2017, 100, 75-86. [CrossRef] [PubMed]

217. De Filippis, B.; Fabbri, A.; Simone, D.; Canese, R.; Ricceri, L.; Malchiodi-Albedi, F.; Laviola, G.; Fiorentini, C. Modulation of RhoGTPases Improves the Behavioral Phenotype and Reverses Astrocytic Deficits in a Mouse Model of Rett Syndrome. Neuropsychopharmacology 2012, 37, 1152-1163. [CrossRef] [PubMed]

218. Valenti, D.; de Bari, L.; De Filippis, B.; Henrion-Caude, A.; Vacca, R.A. Mitochondrial dysfunction as a central actor in intellectual disability-related diseases: An overview of Down syndrome, autism, Fragile $\mathrm{X}$ and Rett syndrome. Neurosci. Biobehav. Rev. 2014, 46, 202-217. [CrossRef] [PubMed]

219. De Filippis, B.; Romano, E.; Laviola, G. Aberrant Rho GTPases signaling and cognitive dysfunction: In vivo evidence for a compelling molecular relationship. Neurosci. Biobehav. Rev. 2014, 46, 285-301. [CrossRef] [PubMed]

220. Gao, Y.; Xing, J.; Streuli, M.; Leto, T.L.; Zheng, Y. Trp56of Rac1 Specifies Interaction with a Subset of Guanine Nucleotide Exchange Factors. J. Biol. Chem. 2001, 276, 47530-47541. [CrossRef] [PubMed]

221. Chan, A.Y.; Coniglio, S.J.; Chuang, Y.; Michaelson, D.; Knaus, U.G.; Philips, M.R.; Symons, M. Roles of the Rac1 and Rac3 GTPases in human tumor cell invasion. Oncogene 2005, 24, 7821-7829. [CrossRef] [PubMed] 
222. Gao, Y.; Dickerson, J.B.; Guo, F.; Zheng, J.; Zheng, Y. Rational design and characterization of a Rac GTPase-specific small molecule inhibitor. Proc. Natl. Acad. Sci. USA 2004, 101, 7618-7623. [CrossRef] [PubMed]

223. De Rubeis, S.; Pasciuto, E.; Li, K.W.; Fernández, E.; Di Marino, D.; Buzzi, A.; Ostroff, L.E.; Klann, E.; Zwartkruis, F.J.T.; Komiyama, N.H.; et al. CYFIP1 coordinates mRNA translation and cytoskeleton remodeling to ensure proper dendritic spine formation. Neuron 2013, 79, 1169-1182. [CrossRef] [PubMed]

224. Zhang, Q.-G.; Wang, R.; Han, D.; Dong, Y.; Brann, D.W. Role of Rac1 GTPase in JNK signaling and delayed neuronal cell death following global cerebral ischemia. Brain Res. 2009, 1265, 138-147. [CrossRef] [PubMed]

225. Sananbenesi, F.; Fischer, A.; Wang, X.; Schrick, C.; Neve, R.; Radulovic, J.; Tsai, L.-H. A hippocampal Cdk5 pathway regulates extinction of contextual fear. Nat. Neurosci. 2007, 10, 1012-1019. [CrossRef] [PubMed]

226. Duffney, L.J.; Wei, J.; Cheng, J.; Liu, W.; Smith, K.R.; Kittler, J.T.; Yan, Z. Shank3 deficiency induces NMDA receptor hypofunction via an actin-dependent mechanism. J. Neurosci. 2013, 33, 15767-15778. [CrossRef] [PubMed]

227. Raynaud, F.; Moutin, E.; Schmidt, S.; Dahl, J.; Bertaso, F.; Boeckers, T.M.; Homburger, V.; Fagni, L. Rho-GTPase-activating protein interacting with Cdc-42-interacting protein 4 homolog 2 (Rich2): A new Ras-related C3 botulinum toxin substrate 1 (Rac1) GTPase-activating protein that controls dendritic spine morphogenesis. J. Biol. Chem. 2014, 289, 2600-2609. [CrossRef] [PubMed]

228. Contini, A.; Ferri, N.; Bucci, R.; Lupo, M.G.; Erba, E.; Gelmi, M.L.; Pellegrino, S. Peptide modulators of Rac1/Tiam1 protein-protein interaction: An alternative approach for cardiovascular diseases. Biopolymers 2017, e23089. [CrossRef] [PubMed]

229. Kuenemann, M.A.; Labbé, C.M.; Cerdan, A.H.; Sperandio, O. Imbalance in chemical space: How to facilitate the identification of protein-protein interaction inhibitors. Sci. Rep. 2016, 6, 1-17. [CrossRef] [PubMed]

230. Costa, C.; Germena, G.; Hirsch, E. Dissection of the interplay between class I PI3Ks and Rac signaling in phagocytic functions. ScientificWorldJournal 2010, 10, 1826-1839. [CrossRef] [PubMed]

231. Astro, V.; Tonoli, D.; Chiaretti, S.; Badanai, S.; Sala, K.; Zerial, M.; De Curtis, I. Liprin- $\alpha 1$ and ERC1 control cell edge dynamics by promoting focal adhesion turnover. Sci. Rep. 2016, 6, 1-16. [CrossRef] [PubMed]

232. Astro, V.; De Curtis, I. Plasma membrane-associated platforms: Dynamic scaffolds that organize membrane-associated events. Sci. Signal. 2015, 8, re1. [CrossRef] [PubMed] 